\title{
A Conceptual Analysis of Early Arabic Algebra
}

\author{
Albrecht Heeffer
}

Abstract Arabic algebra derives its epistemic value not from proofs but from correctly performing calculations using coequal polynomials. This idea of 'mathematics as calculation' had an important influence on the epistemological status of European mathematics until the seventeenth century. We analyze the basic concepts of early Arabic algebra such as the unknown and the equation and their subsequent changes within the Italian abacus tradition. We demonstrate that the use of these concepts has been problematic in several aspects. Early Arabic algebra reveals anomalies which can be attributed to the diversity of influences in which the al-jabr practice flourished. We argue that the concept of a symbolic equation as it emerges in algebra textbooks around 1550 is fundamentally different from the 'equation' as known in Arabic algebra.

\section{Introduction}

The most common epistemology account of mathematics is based on the idea of apriorism. Mathematical knowledge is considered to be independent of experience. The fundamental argument for an apriorist assessment of mathematics is founded on the concept of a formal proof. Truth in mathematics can be demonstrated by deductive reasoning within an axiomatic system. All theorems derivable from the axioms have to be accepted solely on basis of the formal structure. The great mathematician Hardy cogently formulates it as follows (Hardy 1929):

It seems to me that no philosophy can possibly be sympathetic to a mathematician which does not admit, in one manner or another, the immutable and unconditional validity of mathematical truth. Mathematical theorems are true or false; their truth or falsity is absolute and independent of our knowledge of them. In some sense, mathematical truth is part of objective reality.

When some years later, Gödel proved that there are true statements in any consistent formal system that cannot be proved within that system, truth became

\section{A. Heeffer}

Post-doctoral research fellow of the Research Foundation-Flanders (FWO-vlaanderen)

Center for Logic and Philosophy of Science, Ghent University, Belgium

e-mail: albrecht.heeffer@ugent.be 
peremptory decoupled of provability. Despite the fact that Gödel's proof undermined the foundament of apriorism it had little impact on the mainstream epistemological view on mathematics. Only during the past decades the apriorist account was challenged by mathematical empiricism, through influential works from Lakatos (1976), Kitcher (1984) and Mancosu (1996). These authors share a strong believe in the relevance of the history of mathematics for an epistemology of mathematics.

The apriorist view on mathematics has not always been predominant in western thinking. It only became so by the growing influence of the Euclidean axiomatic method from the seventeenth century onwards. With respect to algebra, John Wallis was the first to introduce the axioms in an early work, called Mathesis Universalis, included in his Operum mathematicorum $(1657,85)$. With specific reference to Euclid's Elements, he gives nine Axiomata, also called communes notationes. From then on, the epistemological status of algebra was transformed into one deriving its truth from proof based on the axiomatic method. Before the seventeenth century, truth and validity of an algebraic derivation depended on correctly performing the calculations using an unknown quantity. While Wittgenstein was heavily criticized for his statement that "Die Mathematik besteht ganz aus Rechnung" (Mathematics consists entirely of calculations), (1978, 924; 468), his image of mathematics as procedures performed on the abacus, fits in very well with pre-seventeenth-century conceptions of mathematical knowledge. Algebraical problem-solving consisted of formulating the problem in terms of the unknown and reducing the form to one of the known cases. Early Arabic algebra had rules for each of six known cases. While geometrical demonstrations exist for three quadratic types of problems, the validity of the rules was accepted on basis of their performance in problem-solving.

The idea that European mathematics has always been rooted in Euclidean geometry is a myth cultivated by humanist writings on the history of mathematics. In fact, the very idea that Greek mathematics is our (western) mathematics is based on the same myth, as argued by Jens Høyrup (Høyrup 1996, 103):

According to conventional wisdom, European mathematics originated among the Greeks between the epochs of Thales and Euclid, was borrowed and well preserved by the Arabs in the early Middle Ages, and brought back to its authentic homeland by Europeans in the twelfth and thirteenth century. Since then, it has pursued its career triumphantly.

Høyrup shows that "Medieval scholastic university did produce an unprecedented, and hence specifically European kind of mathematics" (ibid.). But also outside the universities, in the abacus schools of Florence, Siena and other Italian cities, a new kind of mathematics flourished supporting the practical needs of merchants, craftsman, surveyors and even the military man.

Symbolic algebra, the western mathematics par excellence, emerged from algebraic practice within this abacus tradition, situated broadly between Fibonacci's Liber Abbaci (1202, Sigler (2002)) and Pacioli's Summa (1494). Practice of algebraic problem-solving within this tradition grew out of Arabic sources. The epistemic foundations of a mathematics-as-calculation was formed in the Arab world. An explication of these foundations is the prime motivation of our analysis of the basic concepts of early Arabic algebra. 


\section{Starting Point}

While the original meaning of the Arabic concepts of algebra will be an important guideline for this study, we relinquish the search for the "exact meaning". Several scholars have published studies on the origin of the term algebra, the meaning of al-jabr and al-muchäbala and the Arabic terms for an unknown. Some have done so with the aim of establishing the correct meaning with the aid of Arabic etymology and linguistics (e.g. Gandz 1926, Saliba 1972, Oaks and Alkhateeb 2005). Strictly taken, the precise meaning of these Arabic terms and concepts is irrelevant for our study. Even if there would be one exact meaning to be established, it was not available for practitioners of early algebra in Europe. With a few exceptions, such as Fibonacci, ${ }^{1}$ the flourishing of algebraic practice within the abacus tradition depended on a handful of Latin translations and vernacular interpretations or rephrasing of these translations. Unquestionably, certain shifts in meaning took place within the process of interpretation and diffusion during the twelfth and thirteenth centuries. Rather than the Arabic terms and concepts, the concepts conveyed by the first Latin translations will be our starting point.

\subsection{Latin Translations of al-Khwārizmī's Algebra}

Three Latin translations of al-Khwārizmī's Algebra are extant in sixteen manuscripts (Hughes 1982). These translations have been identified as from Robert of Chester (c. 1145), Gerard of Cremona (c. 1150) and Guglielmo de Lunis (c. 1250), although there is still discussion whether the latter translation was Latin or Italian. What became available to the West was only the first part of al-Khwārizmī's treatise. The second part on surveying and the third on the calculation of legacies were not included in these Latin translations. The full text of the Algebra became first available with the edition of Frederic Rosen (1831) including an English translation. Rosen used a single Arabic manuscript, the Oxford, Bodleian CMXVIII Hunt. 214, dated 1342. The value of his translation has been questioned by Ruska (1917), Gandz (1932, 61-3) and Høyrup (1998, note 5). Some years later Guillaume Libri (1838, Note XII, 253-299) published a transcription of Gerard's translation from the Paris, BNF, Lat. 7377A, an edition that has been qualified as 'faulty' and corrected on eighty accounts by Hughes (1986, 211, 231). Later during the century, Boncompagni (1850) also edited a Latin translation from Gerard, but it was later found that this manuscript was not Gerard's but Guglielmo de Lunis' (Hughes 1986). Robert of Chester's translation was first published with an English translation by Karpinski (1915). However, Karpinski used a manuscript copy by Scheubel, which should be seen more as a revision of the original.

It is only during the past decades that critical editions of the three Latin translations have become available. The translation by Gerard of Cremona was edited by Hughes (1986), based on seven manuscript copies. Hughes (1989) also published a critical edition of the first translation from Robert of Chester based on the three extant manuscripts. A third translation has been edited by Wolfgang 
Kaunzner (1986). Although this text (Oxford, Bodleian, Lyell 52) was originally attributed to Gerard, it is now considered to be a translation from Guglielmo de Lunis (Hughes 1982, 1989). An Italian translation from the Latin is recently published by Franci (2003). Hughes (1989) dates this translation at 1313, based on a marginal note in the manuscript. However this dating has recently been refuted by Hissette (2003) and the translation should be situated instead at the first half of the fifteenth century. It has been argued by several scholars that Gerard of Cremona's translation is the best extant witness of the first Arabic algebra (Høyrup 1998).

\subsection{Latin Translations of Other Arabic Works}

Apart from al-Khwārizmī's Algebra there have been Latin translations of other works which contributed to the diffusion of Arabic algebra. The Liber algorismi de pratica arismetrice by John of Seville (Johannes Hispalensis) ${ }^{2}$ precedes the first Latin translations and briefly mentions algebra (Boncompagni 1857, 112-3). Also of importance is Abū Bakr's Liber mensurationum, translated by Gerard of Cremona in the twelfth century (Busard, 1968). Although this work deals primarily with surveying problems it uses the methods as well as the terminology of the early Arabic jabr tradition. Jens Høyrup, who named the method "naive geometry" or "the tradition of lay surveyors", has pointed out the relation between this work and Babylonian algebra (Høyrup, 1986, 1990, 1998, 2002). Following Busard, he has convincingly demonstrated that the operations used to solve these problems are concretely geometrical. Therefore this work can help us with the interpretation of operations in early Arabic algebra.

The Algebra of Abū Kāmil was written some decades after that of alKhwārizmī and bears the same title Kitāb fi al-Jabr wa al-muqābalah. Several versions of the manuscript are extant. An Arabic version MS Kara Mustafa Kütübhane 379 in Istanbul; a fourteenth-century copy of a Latin translation at the BNF at Paris, Lat. 7377A, discussed with partial translations by Karpinski (1914) and published in a critical edition by Sesiano (1993) who attributes the Latin translation to Guglielmo de Lunis $(1993,322-3)$. However, the claim that de Lunis was the translator is troublesome if not only for reasons of dating (Hissette, 1999). A fifteenth-century Hebrew version with a commentary by Mordecai Finzi, is translated in German by Weinberg (1935) and in English by Levey (1966). Levey also provides an English translation of some parts of the Arabic text.

Other texts include Ibn Badr's Ikhtiṣār al-Jabr wa al-muqābala which was translated into Spanish (Sánchez Pérez, 1916) and al-Karajī’s Fakhrī fì al-Jabr wa al-muqābalah with a partial French translation (Woepcke, 1853).

\section{The Evolution of the Concept of an Unknown}

\subsection{The Unknown in Early Arabic Algebra}

The unknown is used to solve arithmetical or geometrical problems. The solution commences with posing an unknown quantity of the problem as the abstract 
unknown. By analytical reasoning using the unknown, one arrives at a value for it. In algebraic problem-solving before Arabic algebra, the abstract unknown is not always the symbolic entity as we now understand. As an essential part of the analytical reasoning, it is an entity related to the context of the problem and the model used for problem-solving. For Babylonian algebra, it is shown by Høyrup (2002) that the model was a geometrical one. The unknown thus refers to geometrical elements such as the sides of a rectangle or a surface. In Indian algebra we find the unknown (or unknowns) used for monetary values or possessions as in the rule of gulikāntara (Colebrooke 1817, 344). The terms used in Arabic algebra reflect both the geometrical interpretation of the unknown as well as the one of a possession. We will argue that the difficulties and confusions in the understanding of the concept of the Arabic unknown are induced by diverse influences from Babylonian and Indian traditions.

\subsubsection{Arabic Terminology}

The central terms in Arabic algebra are māl, shay' and jidhr. In addition, the monetary unit dirham is also used in problems and in their algebraic solutions. It is generally accepted that the term $m \bar{a} l$ refers to possession, or wealth or even a specific sum of money. The shay' is translated as 'thing' ever since the first commentators wrote about it (Cossali 1797-9). From the beginning, shay' was considered the unknown (Colebrooke 1817, xiii).

The difficulties of interpretation arise when we translate $m \bar{a} l$ by 'square' and shay' by 'root'. Rosen (1831) and Karpinski (1915) both use 'square' for $m \bar{a} l$ on most occasions. Karpinski even uses the symbolic $x^{2}$. However, when the problem can be stated without the use of a square term, they both change the interpretation of the $m \bar{a} l$. For example in problem III.11, Rosen uses 'number' and Karpinski employs $x$ instead of $x^{2}$ as used for the other problems. ${ }^{3}$ This already contributes to the confusion as the Latin translation uses the same word in both cases. Moreover the choice of the word 'square' is misleading. Neither the geometrical meaning of 'square', nor the algebraical one, e.g. $x^{2}$, are adequate to convey the meaning of $m \bar{a} l{ }^{4}$ For the geometrical problems, al-Khwārizmī elaborates on the use of $m \bar{a} l$ for the algebraic representation of the area of a geometrical square. If the meaning of $m \bar{a} l$ would be a square, why going through the argumentation of posing $m \bar{a} l$ for the area? ${ }^{5}$ The algebraic interpretation of a square is equally problematic. If $m \bar{a} l$ would be the same as the square of the unknown then jidhr or root would be the unknown. However, this is in contradiction with the original texts in which $m \bar{a} l$, if not the original unknown by itself, is at least transformed into the unknown. Høyrup $(1998,8)$ justly uses the argument that $m \bar{a} l$ is used in linear problems in al-Karajī’s Käfì (Hochheim 1878, iii, 14). This corresponds with the use of a possession in Hindu algebra, in formulating algebraic rules for linear problems, such as the gulikāntara. 
Table 1 The terms used in early Latin translations of Arabic texts (compiled from the original sources)

\begin{tabular}{|c|c|c|c|c|c|}
\hline Arab & $\begin{array}{l}\text { māl } \\
\text { مL }\end{array}$ & $\begin{array}{l}\text { شئيء } \\
\text { shay' }\end{array}$ & 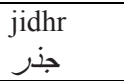 & dirham & $\begin{array}{l}\text { 'adad mufrad } \\
\text { عدد مفرد }\end{array}$ \\
\hline Hispalensis & res & res & radix & $\mathrm{radix} / \mathrm{res}$ & numerus \\
\hline Robert & substancia & res & radix & numerus & numerus \\
\hline Gerard & census & res & radix & drachmae & numerus simplex \\
\hline Guglielmo & census & res & $\mathrm{radix} / \mathrm{res}$ & drachmae/unitates & numerus \\
\hline Abū Kāmil (latin) & census/quantitia $^{6}$ & res/radix & $\mathrm{radix} / \mathrm{res}$ & dragma & numerus simplex \\
\hline
\end{tabular}

\subsubsection{The Ambiguity of $m \bar{a} l$}

The interpretation of $m \bar{a} l$ as the unknown, pure and simple, is not as straightforward as often presented. While māl (in Robert's translation substancia and in Gerard's census) is used to describe the problem, the algebraic derivation depends on operations on other terms than the original 'possession'. Also Hughes points out the problem in his commentary of Robert of Chester's edition: ${ }^{7}$

Terminology also must have jolted Robert's readers. In problems four and six of Chapter I and in five, ten, and thirteen of Chapter II, substancia in the statement of the initial equation becomes res or radix in its solution. Excursions such as these must have challenged the reader.

Let us look more closely at problem III.13, as it is instructive to point out what constitutes a transformation in the original concept of $m \bar{a} l$ :

\begin{abstract}
Karpinski 1930, 118
I multiply a square by two-thirds of itself and have five as a product.

Explanation. I multiply $x$ by twothirds $x$, giving $2 / 3 x^{2}$, which equals five. Complete $2 / 3 x^{2}$ by adding to it one-half of itself, and one $x^{2}$ is obtained. Likewise add to five onehalf of itself, and you have $71 / 2$, which equals $x^{2}$. The root of this, then, is the number which when multiplied by two-thirds of itself gives five.
\end{abstract}

Hughes 1989, 61

Substanciam in eius duabus terciis sic multiplico, ut fiant 5. Exposicio est, ut rem in duabus terciis rei multiplicem, et erunt $2 / 3$ unius substancie 5 coequancia. Comple ergo 2/3 substancie cum similitudine earum medii, et erit substancia. Et similiter comple 5 cum sua medietate, et erit habebis substanciam vii et medium coequantem. Eius ergo radix est res que quando in suis duabus terciis multiplicata feurit, ad quinarium excrescet numerum.

Substancia here is used in the problem text as well as the solution. But clearly it must have a different meaning in these two contexts. In the beginning of the derivation substancia is replaced by res. In the English translation, Karpinski switches from 'square' to $x$. By multiplying the two res terms, $x$ and $2 / 3 x$, two thirds of a new substancia is created. This second substancia is an algebraic concept where the first one, in the problem text, is a possession and may refer to a sum of money. While Gerard of Cremona uses census instead of substancia, his translation has the same ambiguity with regard to census. ${ }^{8}$ 


\subsubsection{The Root of Real Money}

This anomaly of Arabic algebra is discussed now for almost two centuries. Libri (1838), Chasles $(1841,509)$, and others have noticed the problem. Some have chosen to ignore it while others pointed out the inconsistency, but did not provide any satisfactory answer. Very recently, two analyses have reopened the discussion. In the yet to be published Høyrup (2006) and Oaks and Alkhateeb (2005) the double meaning of the $m \bar{a} l$ is prominently present in their interpretation of early Arabic algebra. ${ }^{9}$ Høyrup (2006) adequately describes the anomaly as "the square root of real money". As $m \bar{a} l$ or census originally is understood as a possession, and the unknown is designated by shay' or res, which is the root of the census, problems looking for the value of a possession thus deal with the root of real money when they use the shay' in their solution. According to Høyrup the difference between the two was already a formality for al-Khwārizmī.

\subsubsection{Abū Kämil Towards a Resolution of the Ambiguity}

We find the anomaly also in the algebra of Abū Kāmil, almost a century later. But Abū Kāmil is the first to point out that the transformation of a value or possession into an algebraic quantity is an arbitrary choice. His double solution to problem 52 is very instructive in this respect. The problem commences as follows (translation from the Arabic text, f. 48 ; Levey 1966, 164, note 167):

If one says to you that there is an amount $[m \bar{a} l]$ to which is added the root of its $1 / 2$. Then the sum is multiplied by itself to give 4 times the first amount. Put the amount you have equal to a thing and to it is added the root of its $1 / 2$ which is a thing plus the root of $1 / 2$ a thing, (then multiply it by itself) [sic]. It gives a thing plus the root of $1 / 2$ a thing. Then one multiplies it by itself to give a square plus $1 / 2$ a thing plus the root of 2 cubes [ $\mathrm{ka}$ ' bin, a dual of $k a^{\prime} b$ ] equal to 4 things.

The Latin translation makes the anomaly apparent (Sesiano 1993, 398, 2678-2683):

Et si dicemus tibi: Censui adde radicem medietatis eius; deinde duc additum in se, et provenie[n]t quadruplum census. Exemplum. Fac censum tuum rem, et adde ei radicem medietatis eius, et [prov-] erunt res et radix $1 / 2$ rei. Que duc in se, et provenie[n]t census et $1 / 2$ rei et radix 2 cuborum, equales 4 rebus.

In symbolic representation the solution depends on:

$$
\left(x+\sqrt{\frac{1}{2} x}\right)^{2}=4 x
$$

As is common, the translator uses census for the possession or amount of money in the problem formulation. The solution starts by stating literally 'make from the census your res' ("Fac censum tuum rem") which could easily be misinterpreted as "make $x$ from $x^{2}$ ". In the rest of the solution, res is used as the unknown. 
Abū Kāmil adds a second solution: "You might as well use census for the possession", he reassures the reader (Sesiano 1993, 399, 2701-2705),

Et, si volveris, fac censum tuum censum, et adde ei radicem medietatis ipsius, et erunt census et radix medietatis census, equales radici 4 cens[ibus]uum, [et] quia di[x]cis: "Quando ducimus e[umJa in se, [erit] proveniet quadruplum census". Est ergo census et radix $1 / 2$ census, equales radici $4^{\text {pli }}$ censu[um]s. Et hoc est 2 res.

Here, the symbolic translation would be:

$$
\left(x^{2}+\sqrt{\frac{1}{2} x^{2}}\right)^{2}=4 x^{2}
$$

The census is now used for the possession. But there is still a difference between the census of the problem formulation and the census of the problem solution. "Fac censum tuum censum" should here be understood as "put the amount you have equal to the square of a thing". What Abū Kāmil seems to imply by providing alternative solutions to a single problem, is that there are several ways to 'translate' a problem into algebraic form. The possession in the problem text is not necessarily the unknown. You can use the unknown for the possession, but you might as well use the square of the unknown. In the abacus tradition from the thirteenth to the sixteenth century, this freedom of choice was highly convenient for devising clever solutions to problems of growing complexity. The ambiguity in the concept of $m \bar{a} l$, by many understood as a nuisance of Arabic algebra, could have facilitated the conceptual advance to the more abstract concept of an algebraic quantity.

\subsubsection{Conclusion}

There is definitely an anomaly with the original concept of an unknown in early Arabic algebra. One the one hand, $m \bar{a} l$ is used as the square term in quadratic problems of the type ' $m \bar{a} l$ and roots equal number' such as the prototypical case four from al-Khwārizmī

$$
x^{2}+10 x=39
$$

Early Arabic algebra provides procedures for problems which can be reduced to one of the six standard types. On the other hand, $m \bar{a} l$ is also used for describing the quantity of a problem, mostly a sum of money or a possession. Possibly, at some time before al-Khwārizmī's treatise, these two meanings were contained in a single word and concept. As problems dealing with possessions were approached by algebraic method from the al-jabr tradition, a transformation of the concept $m \bar{a} l$ became a necessity. We notice in al-Khwārizmī's Algebra and all the more in that of Abū Kāmil, a shift towards $m \bar{a} l$ as an algebraic concept different from a 
possession or a geometrical square. The confusion and discontent expressed by several twentieth-century scholars with terminology in early Arabic algebra stems from a failure to see the conceptual change of the $m \bar{a} l$.

We do not know much about the origin of the al-jabr tradition, preoccupied with quadratic problems and their 'naive' geometric demonstrations. Jens Høyrup (1994, 100-2) speculates on a merger of two traditions. The first is the class of calculators employing the his $\bar{a} b$ for arithmetical problem-solving. The second stems from the tradition of surveyors and practical geometers, going back to Old Babylonian algebra. We would like to add the possible influence from Hindu algebra. While the al-jabr tradition is definitely different from the Indian one in methods and conceptualization, the type of problems dealing with possessions are likely to have been imported from the Far East. The ambiguities within the concept of $m \bar{a} l$ reflects the variety of influences.

\subsection{Multiple Solutions to Quadratic Problems}

A second particularity of Arabic algebra is the acceptance of double solutions for one type of quadratic problems. The recognition that every quadratic equation has two roots is generally considered as an important conceptual advance in symbolic algebra. We find this insight in the mostly unpublished works of Thomas Harriot of the early seventeenth century. More influential in this respect, is Girard's Invention Nouvelle en Algebre, published in 1629. However, it is less known that early Arabic algebra fully accepted two positive solutions to certain types of quadratic problems. It is significant that this achievement of Arabic algebra has largely been neglected during the abacus tradition, while it might have functioned as a stepping stone to an earlier structural approach to equations. We believe there is an explanation for this, which is related to the concept of an unknown of the abacus masters. Let us first look at the first occurrence of double solutions in early Arabic algebra.

\subsubsection{Two Positive Roots in Arabic Algebra}

Two positive solutions to quadratic problems are presented in al-Khwārizmī's fifth case of the quadratic problems of "possession and number equal to roots". This problem, in symbolic form, corresponds with the normalized equation

$$
x^{2}+21=10 x
$$

al-Khwārizmī talks about addition and subtraction leading to two solutions in the following rule for solving the problem: 
From Robert's translation (Hughes 1989, 34):

Primum ergo radices per medium dividas et fient 5. Eas ergo in se multiplica et erunt 25. Ex hiis ergo 21 diminuas quem cum substancia iam pretaxauimus, et remanebunt 4 . Horum ergo radicem accipias id est 2, que ex medietate radicum id est 5 diminuas et remanebunt tria, vnam radicem huius substancie constituencia, quam scilicet substanciam novenus complet numerus. Et si volueris ipsa duo que a medietate radicum iam diminuisti, ipsi medietati id est 5 ad 20 dicias, et fient 7.
The rule from the Arabic manuscript (Rosen 1831, 42):

When you meet with an instance which refers you to this case, try its solution by addition, and if that do not serve, then subtraction certainly will. For in this case both addition and subtraction may be employed, which will not answer in any other of the three cases in which the number of the roots must be halved. And know, that, when in a question belonging to this case you have halved the number of the roots and multiplied the moiety by itself, if the product be less than the number of dirhems connected with the square, then the instance is impossible; but if the product be equal to the dirhems by themselves, then the root of the square is equal to the moiety of the roots alone, without either addition or subtraction.

The procedure thus corresponds with the following formula:

$$
x_{1,2}=\frac{b}{2} \pm \sqrt{\left(\frac{b}{2}\right)^{2}-c}
$$

al-Khwārizmī states that the problem becomes unsolvable when the discriminant becomes negative. When the square of $b / 2$ equals the number (of dinars) there is only one solution which is half the number of roots. The gloss in Gerard's translation of problem VII.1 gives a geometric demonstration with the two solutions. This problem from al-Khwārizmī is also treated by Abū Kāmil (Karpinski 1914, 42-3; Sesiano 1993, 330-6). A lesser known Arabic manuscript, which most likely predates al-Khwārizmī, also has the geometric demonstration with double solutions (Sayili 1985, 163-5).

Chasles $(1841,504)$ mentions a Latin translation of Gerard (Paris, BNF, anciens fonds 7266) from a treatise on the measurement of surfaces, by an Arab called Sayd. A problem of the same type, corresponding with the symbolic equation

$$
x^{2}+3=4 x
$$

is solved by addition and subtraction ("Hoc namque est secundum augmentum et diminutionem"), referring to the values $x=2+1$ and $x=2-1$, resulting in the double solution $x=3$ and $x=1$.

In conclusion: double positive solutions to one type of quadratic problems were fully accepted in the earliest extant sources of Arabic algebra.

\subsubsection{Speculation on the Origin of Double Solutions}

Dealing with quadratic problems, Diophantus never arrives at double solutions. If the problem has two positive solutions, he always finds the larger one (Nesselmann 1842, 319-21; Tropfke 1933-4, 45). So, where do the double solutions of Arabic 
type V problems originate from? If not from Greek descent, the most likely origin would be Hindu algebra. However, Rodet (1878) was the first to critically investigate the possible influence of Hindu sources on Arabic algebra. One of his four arguments against such lineage is the difference in approach to double solutions of the quadratic equation. As the Hindus accepted negative values for roots and numbers they had one single format for complete quadratic equations, namely

$$
a x^{2} \pm b x= \pm c
$$

whereas the Arabs had three types. The Hindu procedure for solving complete quadratic problems accounts for double solutions as stated by Bhāskara (and his predecessors): ${ }^{10}$

If the root of the absolute side of the equation be less than the number, having the negative sign, comprised in the root of the side involving the unknown, then putting it negative or positive, a two-fold value is to be found of the unknown quantity: this [holds] in some cases.

The "root of the absolute side of the equation" refers to the $\pm c$. The Hindu procedure to find the roots of a quadratic equation can be illustrated by the following example (Bhāskara stanza 139; Colebrooke 1817, 215-6):

The eighth part of a troop of monkeys, squared, was skipping in a grove and delighted with their sport. Twelve remaining were seen on the hill, amused with chattering to each other. How many were they in all?

Using the unknown ya 1 for the number of monkeys, Bhāskara solves the problem as follows:

$$
\begin{array}{ccc}
y a v \frac{1}{64} & \text { ya } 0 & \text { ru } 12 \\
y a v 0 & \text { ya } 1 & \text { ru } 0 \\
\text { ya } v 1 & \text { ya } 6 \dot{4} & \text { ru } 0 \\
\text { ya } v 0 & \text { ya } 0 & \text { ru } 7 \dot{6} 8
\end{array}
$$

yа 1 ru $3 \dot{2}$

yа 0 ru 16 literally transcribed:

$$
\frac{1 x^{2}}{64}+0 x+12=0 x^{2}+x+0
$$

bringing to the same denominator:

$$
x^{2}-64 x=-768
$$

making the left side a perfect square:

$$
(x-32)^{2}=256
$$

extracting the root results in: $x-32= \pm 16$

The two solutions thus become $x=48$ and $x=16$.

In the next problem the acceptance of two solutions is more challenging (Bhāskara stanza 140; Colebrooke 1817, 216):

The fifth part of the troop [of monkeys] less three, squared, had gone to a cave; and one monkey was in sight, having climbed on a branch. Say how many they were. 
This leads to the equation:

$$
\begin{array}{llll}
y a v 1 & y a 5 \dot{5} & r u 0 & \text { literally transcribed: } \\
y a v 0 & \text { ya } 0 & r u 250 & 1 x^{2}-55 x+0=0 x^{2}+0 x-250
\end{array}
$$

with solutions $x=50$ and $x=5$. Bhāskara has some reservations about the second solution because one fifth of five minus three becomes negative.

The very different approach towards quadratic problems and the acceptance of negative roots in Hindu algebra makes it an improbable source for the double solutions of type $\mathrm{V}$ problems in Arabic algebra.

If not from Greek or Indian origin, there is only one candidate left. Solomon Gandz, in an extensive, and for that time, exhaustive comparison of solutions to quadratic problems from Babylonian, Greek and Arabic origin concluded (Gandz 1937, 543):

Greek and Arabic algebra are built upon the rock of the old Babylonian science and wisdom. It is the legacy of the old Babylonian schools which remain the very foundation and cornerstone of both the Greek and Arabic systems of algebra. The origin and early development of the science cannot be understood without the knowledge of this old Babylonian legacy.

Although the relation should now be qualified and differentiated more cautiously, recent studies, such as the groundbreaking and novel interpretation by Høyrup (2002) endorse some line of influence. If we look again at the type V problem from al-Khwārizmī, the resulting equation

$$
x^{2}+21=10 x
$$

which is given in its direct form, corresponds remarkably well with a standard type of problem from Babylonian algebra:

$$
\begin{aligned}
& a+b=10 \\
& a b=21
\end{aligned}
$$

The important difference between the two is that Babylonian algebra uses a geometrical model for solving problems. The two parts $a$ and $b$ are represented as the sides of a rectangle $a b$ and they function as two unknowns in the meaning we have defined elsewhere. ${ }^{11}$ Arabic algebra uses geometry only as a demonstration of the validity of the rules and its analytic part is limited to reducing a problem to one of the standard forms using a single unknown. al-Khwārizmī systematically uses the unknown for the smaller part. Thus in problem VII he proceeds as follows (de Lunis; Kaunzner 1986, 78):

Ex quarum unius multiplicatione per alteram 21 proveniant. Sit una illarum res, altera 10 minus re, ex quarum multiplicatione proveniunt 10 res minus censu, que data sunt equalia 21. Per restaurationem igitur diminuti fiunt 10 res censui ac 21 equales ecce quintus modus, resolve per eum et invenies partes 3 et 7 . 
al-Khwārizmī multiplies $x$ with $10-x$, with value 21. After "restoration" this leads to the standard form of the equation above. While the rule for type $\mathrm{V}$ prescribes trying addition first and then subtraction (in the Robert translation), the solutions arrived at here are 3 first and then 7 . We believe that the recognition of two solutions to this type of quadratic problem is a direct relic of the Babylonian solution method.

Although the geometric proof for this problem, present in the Arabic texts and the three Latin translations, does not correspond with any known Babylonian tablets, some of al-Khwārizmī’s geometric demonstrations ought to be placed within the surveyor's tradition which descends in all probability from Old Babylonian algebra.

Høyrup (2002, 412-4) points out that al-Khwārizmī’s provides two rather different geometrical demonstrations to the case "possessions and roots equal number". Only one corresponds with the procedure described in the text. The other, shown in Fig. 1, corresponds re-

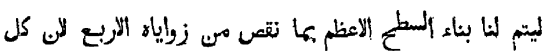

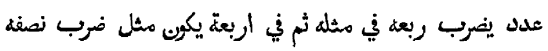

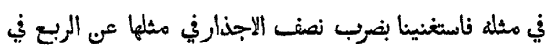

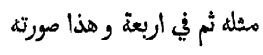

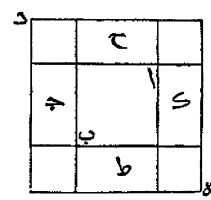

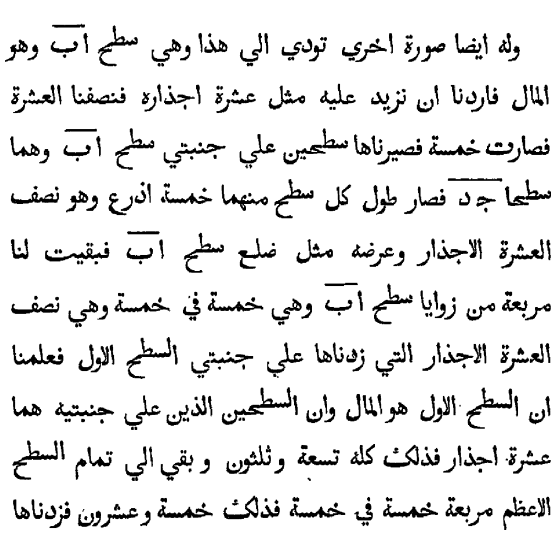

Fig. 1 A geometrical demonstration by al-Khwārizmī (from Rosen 1831, 10) markably well with the Babylonian table BM 13901, nr. 23.

According to Høyrup, al-Khwārizmī’s proof must have been derived from this tradition. This way of demonstrating may then have been more familiar than the al-jabr itself.

\subsubsection{Double Solutions in the Abacus Tradition}

We continue to find double solutions in the early abacus tradition. The first vernacular algebra by Jacopa da Firenze (1307, Vatican, Lat. 4826) mentions double solutions to the fifth type, both in the rules and in the corresponding examples. Maestro Dardi (1344, van Egmond 1983), in an extensive manuscript some decades later, continues to account for double solutions (Franci 2001, 83-4). Significantly, he leaves out the second positive solution for the geometrical demonstration of $x^{2}+21=10 x$ which is copied from the Arabic texts. Later treatises gradually drop the second solution for this type of problem. For example, the anonymous 
Florence Fond. Prin. II.V.152, later in the fourteenth century, has an intermediate approach. The author writes that:

In some cases you have to add half the number of cosa, in others you have to subtract from half the number of cosa and there are cases in which you have to do both.

However, when applying the rule to an example with two positive solutions, he proceeds to perform only the addition. ${ }^{12}$ For the equation

$$
x^{2}+9=10 x
$$

he gives the solution $x=9$ and does not mention the second root $x=1$. Also Maestro Biagio mentions addition and subtraction in his sixth rule but only applies the addition operation, as in problem 3 where two positive solutions are possible (Pieraccini 1983, 3).

Later abacus masters abandon the second solution altogether. For example the Riccar. 2263 gives only one solution to the problem $a+b=10, a b=22$ (Simi 1994, 33). Pacioli only uses addition for the fifth case of the quadratic problems (Pacioli 1494, 145). Maestro Gori, in the early sixteenth century, generalizes his rules to a form where the powers of the unknown are relative to each other. The Arabic rule V corresponds with his rule 4 in which "one finds three terms in continuous proportion of which the major and the minor together equal the middle one" (Siena L.IV.22, f. $75^{\text {r}}$; Toti Rigatteli 1984, 16). This corresponds with the equation type

$$
a x^{2 n}+c=b x^{n}
$$

Here Gori is in complete silence about a second possible solution, in the explanation of the rule, as well as in the examples given.

\subsubsection{Double Solutions Disappearing from Abacus Algebra}

Why do we see these double solutions for quadratic problems fading away during algebraic practice in the abacus tradition? It could be interpreted as an achievement of Arabic algebra which becomes obscure in vernacular writings. In our understanding, the abandonment of double solutions has to be explained through the rhetorical structure employed by abacus writers. The strict, repetitive and almost formalized structure of the problem solution text is a striking feature of many of the algebraic manuscripts in Italian libraries. The solution always starts with a hypothetical reformulation of the problem text by use of an unknown. For example, Gori, as an illustration of the rule cited above, selects a division problem of ten into two parts with certain conditions given. The solution commences in the typical way "suppose that the smaller part equals one cosa" ("pongho la minor parte sia 1 co.", ibid. p. 17). One particular value of the problem is thus represented by the unknown. The unknown here is no indeterminate as in later algebra; it is an abstract representation for one specific quantity of the problem. Given that this recurring rhetoric structure, which is so important for the abacus tradition, commences by posing one specific value, it makes no sense to end up with two values 
for the unknown. For the type of division problems which have descended from Babylonian algebra the quadratic expression leads to the two parts of the division. However, if one starts an argumentation stating that the cosa represents the smaller part, one does not expect to end up with the value of the larger part. The concept of an unknown in the abacus tradition is closely connected with this rhetorical structure in which the choice of the unknown excludes double solutions by definition.

\subsection{The Unknown in the Abacus Tradition}

With al-Khwārizmī's treatise and more so with Abū Kāmil's Algebra, the unknown became a more abstract concept, independent of a geometrical interpretation. While the unknown in one type of quadratic problems allowed for double solutions, this was gradually reduced to a single value through the rhetorical structure of abacus treatises. Let us now summarize the development of the concept unknown within the abacus tradition.

The ambiguity of the $m \bar{a} l$ was carried over, to some degree, from the Arabic texts to the abacus tradition by Fibonacci. Høyrup (2000, 22-3) has pointed out the inconsistent use of Latin words for shay' and māl by Fibonacci. ${ }^{13}$ For most of the algebra part, Fibonacci uses the res and census terminology of Gerard of Cremona. However, in the middle of chapter 15 he switches from census to avere for $m \bar{a} l$ (Sigler 2002, 578-601). For Høyrup this is an indication that vernacular treatises may have been circulating around 1228, the time of the second edition of the Liber abbaci. The Milan Ambrosiano P 81 sup, (fols. $\left.1^{r}-22^{r}\right)$ is a later revision of Gerard's translation. Here the author uses cosa for res (Hughes 1986, 229). While this manuscript is probably of later origin, the use of the vernacular cosa rather than census or res is characteristic for the abacus tradition. With the first vernacular algebra extant, by Jacopa da Firenze in 1307, the use of cosa removed most of the original ambiguities. Where the conversion from the $m \bar{a} l$ as a possession to the $m \bar{a} l$ as an algebraic entity will have defied the student of Arabic algebra, the vernacular tradition eliminated these difficulties. When Jacopa provides the solution to a problem on loan interest calculation he commences as follows (Høyrup 2000, 30):

Fa così: pone che fusse prestata a una cosa el mese de denaro, sì che vene a valere l'anno la libra 12 cose de denaro, che 12 cose de denaro sonno el vigensimo de una libra, sì che la libra vale l'anno 1/20 [de cosa] de una libra.

By posing that the loan was lent at one cosa in denaro a month, the calculation can be done in libra leading to a quadratic equation with a standard solution. The rhetorical structure of the solution text starts from a conversion of a quantity of the problem, in this case the number denari lent, to an unambiguous unknown cosa. Reformulating the problem in terms of the unknown, the problem can be solved by reducing the formulation to a known structure. In this case to censi and cosa equal to numbers. 
This was basically the function and meaning of the cosa for the next two centuries within the abacus tradition. In all, the notion of the unknown in the abacus tradition was fairly constant and unproblematic.

\section{Operations on Polynomials}

Most current textbooks on the history of algebra consider operations on polynomial expressions as natural to a degree that they do not question the circumstances in which these operations emerged. This is rather peculiar as most algebra textbooks, from the late abacus tradition onwards, explain these operations at length in their introduction. Focusing on the operations which have led to the formation of new concepts, we consider operations on polynomials crucial in the understanding of the equation as a mathematical concept. A possible reason for this neglect of conceptual innovations is the structural equivalence of algebraic operations with arithmetical or geometrical ones.

al-Khwārizmī (c. 850) introduces operations on polynomials in the Arabic version of his Algebra after the geometrical proofs and before the solution to problems. Strangely, he treats multiplication first, to be followed by a section on addition and subtraction, and he ends with division. Algebraic and irrational binomials are discussed interchangeably. Geometrical demonstrations are provided for the irrational cases. This order is followed in the three Latin translations. Abu Kāmil in his Algebra (c. 910) extends the formal treatment of operations on polynomials from al-Khwārizmī with some geometrical demonstrations and some extra examples, and moves division of surds to the first part. Al-Karkhī (c. 1000) improves on the systematization, but still follows the order of multiplication, division, root extraction, addition and subtraction. He treats surds after algebraic polynomials.

Hindu and Arabic treatments of operations on polynomials differ too widely to suspect any influence from either side. The order of operations and the way negative terms are treated are systematically dissimilar in both traditions. Nonetheless, there is the historical coincidence in the introduction of operations on polynomials in two dispersed traditions.

\subsection{The Abacus and Cossic Tradition}

Although Fibonacci's algebraic solutions to problems use operations on polynomials throughout chapter 15 , he does not formally discuss the subject as known in Arabic algebra. Typically, such preliminaries are skipped in early abacus writings and the authors tend to move directly to their core business: problem-solving. A formal treatment of operations on polynomials is found gradually from the fourteenth century onwards.

Maestro Dardi in his Aliabraa argibra commences his treatise with an extensive section dealing with operations on surds (1344, Siena I.VII.17, fols. $3^{\mathrm{v}}-14^{\mathrm{r}}$; Franci 2001). A short paragraph deals with the multiplication of algebraic binomials 
in between the geometrical demonstrations and the problems (ibid. fol. 19v ). This is the location where we found the subject in al-Khwārizmī's Algebra. As far as we know, the anonymous Florence Fond. prin. II.V.152 dated 1390, is the first abacus text which has a comprehensive treatment on the multiplication of polynomials (fols. $145^{\mathrm{r}}-152^{\mathrm{r}}$; Franci and Pancanti 1988, 3-44). It provides numerous examples with binomials and trinomials, including roots and higher powers of the unknown. Some curious examples are

$$
(8 x+0)(9 x+5)
$$

a form including a zero term we are familiar with from Hindu algebra, and the complex form

$$
\left(6 x^{5}+6 x^{4}+6 x^{3}+6 x^{2}+6 x+6\right)\left(6 x^{5}+6 x^{4}+6 x^{3}+6 x^{2}+6 x+6\right)
$$

Still, the examples are limited to multiplying polynomials.

During the fourteenth century, such introduction becomes more common and with the anonymous Modena 578 (1485, van Egmond 1986) we find a more systematic treatment of the addition, subtraction and multiplication of unknowns and polynomials. Finally, Pacioli (1494) raises the subject to the level of an algebra textbook.

\section{The Symbolic Equation as a Novel Concept}

\subsection{The Concept of an Equation in Arabic Algebra}

Because the following paragraphs will deal with operations on equations, we have to make clear what the meaning is of an equation in early Arabic algebra. In fact, there are no equations in Arabic algebra as we currently know them. However, some structures in Arabic algebra can be compared with our prevailing notion of equations. Many textbooks dealing with the history of algebraic equations go back to Babylonian algebra. So, if there are no equations in Arabic algebra, what are they talking about? Let us therefore try and interpret the concept within Arabic algebraic treatises.

Some basic observations on early Arabic algebra should not be ignored:

- The Latin translations do not talk about equations but about rules for solving certain types of quadratic problems. This terminology is used throughout: "the first rule", "demonstration of the rules", "examples illustrating the rules", "applying the fourth rule", etc. Apparently, these rules can be transformed directly into symbolic equations, but this is true for many other rules which cannot even be considered algebraic, such as medieval arithmetical solution recipes. $^{14}$

- There is no separate algebraic entity in al-Khwārizmī's treatise which corresponds with an equation. The closest we get to an entity are "modes of 
equating" or "the act of equating", referring to actions, not to a mathematical entity. The best way to characterize a mathematical entity is by the operations which are allowed on it. In early Arabic algebra there are no operations on equations. On the other hand, there are operations on polynomials. al-Khwārizmì has separate chapters on these operations.

- Early Arabic algebra is preoccupied with quadratic problems. Although linear problems are later approached algebraically by al-Karkhī, no rules are formulated for solving linear problems, as common in Hindu algebra. Therefore, if we consider the rules for solving quadratic problems equations, then there is no analogous case for linear problems.

The correct characterization of the Arabic concept of an equation is the act of keeping related polynomials equal. Guglielmo de Lunis and Robert of Chester have a special term for this: coaequare. In the geometrical demonstration of the fifth case, de Lunis proves the validity of the solution for the "equation"

$$
x^{2}+21=10 x
$$

The binomial $x^{2}+21$ is coequal with the monomial $10 x$, as both are represented by the surface of a rectangle (Kaunzner 1989, 60):

Ponam censum tetragonum abgd, cuius radicem ab multiplicabo in 10 dragmas, quae sunt latus be, unde proveniat superficies ae; ex quo igitur 10 radices censui, una cum dragmis 21 , coequantur.

Once two polynomials are connected because it is found that their arithmetical value is equal, or, in this case, because they have the same geometrical interpretation, the continuation of the derivation requires them to be kept equal. Every operation that is performed on one of them should be followed by a corresponding operation to keep the coequal polynomial arithmetical equivalent. Instead of operating on equations, Arabic algebra and the abacus tradition operate on the coequal polynomials, always keeping in mind their relation and arithmetical equivalence. At some point in the history of algebra, coequal polynomials will transform into an equation. Only by drawing the distinction, we will be able to discern and understand this important conceptual transformation. We will now investigate how and when this transformation took place.

\subsection{Operations on 'equations' in Early Arabic Algebra}

Much has been written about the origin of the names al-jabr and al-muchäbala, and the etymological discussion is as old as the introduction of algebra into western Europe itself. We are not interested in the etymology as such (as does for example Gandz 1926) but in the concepts designated by the terms. The older writings wrongly refer to the author or inventor of algebra by the name Geber. Several humanist writers, such as Ramus, chose to neglect or reject the Arabic roots of Renaissance algebra altogether (Høyrup 1998). Regiomontanus's Padua lecture of 1464 was probably the most damaging for a true history of algebra. John 
Wallis, who was well-informed on Arabic writings through Vossius, attributes the name algebra to al-jabr w'al-muchābala in his Treatise on Algebra and points at the mistaken origin of Geber's name as common before the seventeenth century (Wallis 1685,5 ). He interprets the two words as operations and clearly not as Arabic names: ${ }^{15}$

The Arabic verb Gjäbara, or, as we should write that found in English letters, jābara (from whence comes the noun al-gjābr), signifies, to restore ... The Arabic verb Käbala (from whence comes the noun al-muläbala) signifies, to oppose, compare, or set one thing against another.

Montucla (1799, I, 382) repeats Wallis' comments on Geber by Wallis but seems to interpret al-muchäbala as the act of equating itself:

Suivant Golius, le mot arabe, gebera ou giabera, s'explique par religavit, consolidavit; et mocabalat signifie comporatio, oppositio. Le dernier de ces mots se rapporte assez bien à ce qu'on fait en algèbre, dont une des principales opérations consiste à former une opposition ou comparaison à laquelle nous avons donné le nom d'équation.

We want to understand the concept of the 'equation' within the context of the dissemination of early Arabic algebra in western Europe. We will approach this conceptual reconstruction from the operations that were performed on the structures we now call equations. Changes in the operations on these structures will allow us to understand the changes in the concept of an equation. In a fairly recent publication, Saliba (1972) analyzed the possible meanings of al-jabr and other operations in the Arabic text of the Kitāb al-mukhtașar fì Hisāb al-Jabr wa al-Muqābalah (c. 860) by al-Khwārizmī, but also the lesser-known works Kitāb al-Bad $\bar{l}^{\prime}$ fì al-Hisāa (Anbouba, 1964), Kitāb al-Kāfi fì al-Hisāb by al-Karaj̄i (c. 1025), and its commentaries, the Kitāb al-Bāhir fì 'ilm al-Hisāa by Ibn Abbās (twelfth century) and the Kitāb fi al-Jabr wa al-Muqābalah from Ibn Amr al-Tannūkhī al-Ma arrī. Concerning the use of operations, Saliba concludes (1972, 190-1):

We deduce from them the most common definitions of the algebraic operations commonly denoted in those texts by the words jabr, muqābala, radd and $\bar{i} k m a l$.

The understanding of the precise meaning of these operations is an ongoing debate since the last century and earlier. There are basically two possible explanations. Either the Arabic authors of algebra treatises terms used the term inconsistently, or there are fundamental difficulties in understanding their meaning. Saliba is clearly convinced of the former, and seizes every opportunity to point at differences in interpretation and double uses of some terms. Others believe that there are no inconsistent uses at all and attempt to give an interpretation of their own. A recent discussion, on the Historia Mathematica mailing list, has raised the issue of interpretation once again. ${ }^{16}$ Jeffrey Oaks writes that:

the words used to describe the steps of algebraic simplification, ikmāl (completion), radd (returning), jabr (restoration) and muqābala (confrontation), are not technical terms for specific operations, but are non-technical words used to name the immediate goals of particular steps. It then follows, contrary to what was previously thought, that alKhwārizmī and other medieval algebraists were not confusing and inconsistent in their uses of these words. 
We do not want to be unsporting by claiming that a middle position is here more appropriate. We tend to defend the latter position. While there may be some inconsistent uses of the terms between authors and possibly even within a single treatise, the proper meaning of the operations can be well established within the context in which they occur. We will show that some confusions can be explained by translating or scribal errors and that a symbolic interpretation of the operations as Saliba's is highly problematic. We found out that while our interpretation of the al-jabr operation is new with respect to most twentieth-century discussions, it is not divergent from nineteenth-century studies, as Chasles' (1841) and Rodet's (1878).

\subsubsection{Al-jabr}

\subsubsection{Early Occurrences}

The jabr operation is commonly interpreted as "adding equal terms to both sides of an equation in order to eliminate negative terms". ${ }^{17}$ It appears first in alKhwārizmī's book in the first problem for the 'equation' $x^{2}=40 x-4 x^{2}$. In this interpretation the al-jabr is understood as the addition of $4 x^{2}$ to both parts of the equation in order to eliminate the negative term in the right-hand part. As a typical symbolical interpretation we give the description from Saliba $(1972,192)$ :

If $f(x)-h(x)=g(x)$, then $f(x)=g(x)+h(x)$; which is effected by adding $h(x)$ to both sides of the equation and where $f(x), h(x), g(x)$ are monomials. E.g. if $x^{2}-10 x=19$ then $x^{2}=19+10 x$

Saliba (1972) points out that the Arabic root jabara has a double meaning. On the one hand 'to reduce a fracture', on the other 'to force, to compel'. He believes the second interpretation is justified as it corresponds with his mathematical understanding. We will argue the contrary.

Surprisingly, the symbolic interpretation such as van der Waerden's (1985) and Saliba's has, until very recently, never been challenged. The rule corresponds with one of the later axioms of algebra: you may add the same term to both sides of an equation. ${ }^{18}$ As such, the rule seems to be in perfect correspondence with our current understanding of algebra. However, we will show this is not the case.

Let us follow the available translations of the original text. The first of alKhwārizmī's illustrative problems is formulated as the division of 10 into two parts such that one part multiplied by itself becomes four times as much as the two parts multiplied together. Using the unknown for one of the parts, the other is 10 minus the unknown. al-Khwārizmī proceeds as follows (Rosen 1831, 35-6):

Then multiply it by four, because the instance states "four times as much". The result will be four times the product of one of the parts multiplied by the other. This is forty things minus four squares. After this you multiply thing by thing, that is to say one of the portions by itself. This is a square, which is equal to forty things minus four squares. Reduce it now by the four squares; and add them to the one square. Then the equation is: forty things are equal to five squares; and one square will be equal to eight roots, that is, 
sixty-four; the root of this is eight, and this is one of the two portions, namely, that which is to multiplied by itself.

The jabr operation is thus described by "reduce it now by the four squares, and add them to the one square". Remark that this description is somewhat odd. The operation here seems to consist of two steps, first reducing the four squares from it and secondly, adding them to the one square. For the second problem, Rosen (1831, 37) also uses the term reduce in the context "Reduce it to one square, through division by nine twenty-fifths", which is clearly a different type of operation of division by a given factor. On most other occasions Rosen translates the jabr operation as "separate the $<$ negative part $>$ from the $<$ positive part $>$ ". ${ }^{19}$ Karpinski's translation gives a different interpretation. He used Scheubel's copy of the Latin translation by Robert of Chester and translates the passage as "Therefore restore or complete the number, i.e. add four squares to one square, and you obtain five squares equal to 40x" (Karpinski 1915, 105). Karpinski does not use 'restore' in the second sense. In his view, restoring describes a one-step operation. The addition of the four squares to the one square explains the act of restoration. Can we find this interpretation confirmed by the first Latin translations?

Although we find in Hispalensis (Boncompagni 1857, 112-3) a corrupted version of the title of al-Khwārizmī's book, "Exceptiones de libro qui dicitur gleba mutabilia", al-jabr is not further discussed..$^{20}$ The jabr operation is most commonly translated into Latin by the verb restaurare and appears only once in Robert of Chester's translation for this problem (Hughes 1989, 53): "Restaura ergo numerum et super substanciam 4 substancias adicias" which literally means "Therefore restore the number and to the square term add 4 square terms". The other occurrence is in the title Liber Algebre et Almuchabolae de Questionibus Arithmetic(i)s et Geometricis. In nomine dei pii et misericordis incipit Liber Restauracionis et Opposicionis Numeri quem edidit Mahumed filius Moysi Algaurizmi. Robert also uses the verb complere twice as an alternative translation for al-jabr (Hughes 1989, 56:1, 57:21).

The second Latin translation by Gerard of Cremona (c. 1150) uses restaurare eleven times. For the first problem Gerard formulates the jabr operation as "deinde restaurabis quadraginta per quatuor census. Post hoc addes census censui, et erit quod quadraginta res erunt equales quinque censibus". ${ }^{21}$ Thus, the two Latin translations agree. Translated in symbolic terms, when given $40 x-4 x^{2}=x^{2}$, the $40 x$ is restored by the $4 x^{2}$ and only then, post hoc, the $4 x^{2}$ is added to the $x^{2}$. If we look at the actual text used by Karpinski (published by Hughes 1989, 53) "Restaura ergo numerum et super substancia, 40 rebus absque 4 substancias adicias, fientque 40 res 5 substancias coequentes", the same interpretation can be justified. The $a l-j a b r$ or restoration operation consists of completing the original term $40 x$. It is considered to be incomplete by the missing four censi. The addition of the four censi to the census is a second step in the process, basically different from the $a l$-jabr operation. The other occurrences of the operations within the problem sections are listed in the Table 2. 
Table 2 All the occurrences of the restoration operation in al-Khwārizmī's' Algebra in the Latin translation by Robert of Chester

\begin{tabular}{|c|c|c|c|}
\hline Prob & Meta-description & Actual text & pp. \\
\hline VI.1 & $x^{2}=40 x-4 x^{2}$ & $\begin{array}{l}\text { Deinde restaurabis quadraginta per } \\
\text { quattuor census. Post hoc addes } \\
\text { census censui }\end{array}$ & $247-248$ \\
\hline VI.3 & $4 x=10-x$ & $\begin{array}{l}\text { Restaura itaque decem per rem, et adde } \\
\text { ipsam quattuor. }\end{array}$ & 248 \\
\hline VI.5 & $100+2 x^{2}-20 x=55$ & $\begin{array}{l}\text { Restaura ergo centum et duos census } \\
\text { per res que fuerunt diminute, et adde } \\
\text { eas quinquaginta octo. }\end{array}$ & 249 \\
\hline VII.1 & $10 x-x^{2}=21$ & $\begin{array}{l}\text { Restaura igitur decem excepta re per } \\
\text { censum, et adde censum viginti uno. }\end{array}$ & 250 \\
\hline VII.4 & $21 x+\frac{2}{3} x-2 x^{2}-\frac{1}{6}=100+2 x^{2}-2 x$ & $\begin{array}{l}\text { Restaura ergo illud, et adde duos census } \\
\text { et sextam centum et duobus censibus } \\
\text { exceptis viginti rebus }\end{array}$ & 251 \\
\hline VII.5 & $100+x^{2}-20 x=\frac{1}{2} x$ & $\begin{array}{l}\text { Restaura igitur centum et adde viginti } \\
\text { res medietati rei. }\end{array}$ & 252 \\
\hline VII.6 & $100+x^{2}-20 x=81 x$ & $\begin{array}{l}\text { Restaura ergo centum, et adde viginti } \\
\text { radices octoginta uni. }\end{array}$ & 252 \\
\hline \multirow{2}{*}{ VII.8 } & $52 \frac{1}{2}-10 \frac{1}{2} x=10 x-x^{2}$ & \multirow{2}{*}{$\begin{array}{l}\text { Restaura ergo quinquaginta duo et } \\
\text { semis per decem radices et semis, et } \\
\text { adde eas decem radicibus excepto } \\
\text { censu. } \\
\text { Deinde restaura eas per censum et } \\
\text { adde censum quinquaginta duobus et } \\
\text { semis. }\end{array}$} & 253 \\
\hline & $52 \frac{1}{2}=20 \frac{1}{2} x-x^{2}$ & & 253 \\
\hline VIII.1 & $100+x^{2}-20 x=81$ & $\begin{array}{l}\text { Restaura ergo centum et adde viginti } \\
\text { radices octoginta uni et erunt centum et } \\
\text { census. }\end{array}$ & 257 \\
\hline
\end{tabular}

With this exhaustive list of all occurrences of the jabr operation in alKhwārizmī's' Algebra we can now draw an interpretation for the meaning of the operation: ${ }^{22}$

- The restoration is an operation which reinstates a polynomial to its original form. We use polynomial as a generalization of the several cases. In VI.4 it is a simple number which is being restored. Also cases VII.5 and VII.6 refer to the single number 100 , instead of $100+x^{2}$. However in problem VI.5 is the binomial $100+2 x^{2}$ which is restored. This is consistent with the other Latin translations.

- The restoration consists of adding (back) the part which has been diminished ("que fuerunt diminute") to the polynomial. The restoring part can itself be a polynomial, as in problem VII.4 with $2 x^{2}-1 / 6$ as the restoring part.

- The restoration operation is always followed by the addition of the restoring part to the other (coequal) polynomial. 
In such interpretation of Arabic algebra, the basic operation of al-jabr, from which the name of algebra is derived, does not consist of adding a negative term to the two parts of an equation. Instead, it refers to the completion of a polynomial which is considered incomplete by the presence of what we now would call, a negative term. An understanding of $a l-j a b r$ in early Arabic algebra is inextricably bound with a geometric interpretation. We conjecture the al-jabr operation to be a generalization of the basic geometrical acts like cutting and pasting as we know them from Babylonian algebra. The original use of the restoration may refer to the restoration of a geometrical square. As we have discussed above, the $m \bar{a} l$ as the Arabic concept of the unknown is a mixture of the meaning of possession, known from Hindi sources and from the geometrical square. While the original form of the jabr operation may have been purely geometrical, the operation can easily be generalized to simple numbers or polynomials. The demonstration of the solution to the quadratic problems in chapter 7 of al-Khwārizmī's Algebra gives us the most likely context of interpretation. Given that $x^{2}+10 x=39$, the demonstration depends on the completion of the polynomial $(x+5)^{2}-25$ with value 39 (see Fig. 2). The jabr operation restores the $m \bar{a} l$, the square term, in the polynomial. Hence, the value of the completed square $(x+5)^{2}$ can be determined through a separate operation of adding 25 to 39 . Also the third translation, by Guglielmo de Lunis (c. 1250), uses restauracio. In eight problems the operation is applied in the same meaning as the two other translations. We will therefore not discuss these further. ${ }^{23}$

However, in two similar problems, 4 and 6, restaurare is also used for a different kind of operation. This happens in situations where an expression involves a fraction of the $m \bar{a} l$ as in

$$
\frac{1}{12} x^{2}+1+\frac{1}{3} x+\frac{1}{4} x=20 \text { and } \frac{1}{12} x^{2}=x+24
$$

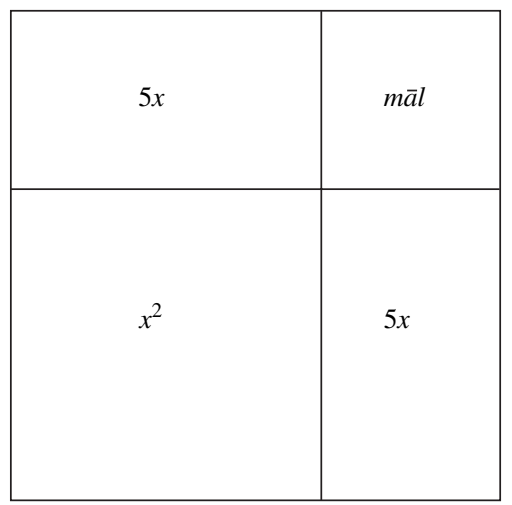

Fig. 2 completing the square (from al-Khwārizmī) 
In these two cases restaurare consists of multiplying the polynomials by 12 . This operation is called al-ikmāl in Arabic and will be discussed below.

\subsubsection{Al-jabr in Later Arabic Sources}

Let us verify if this new interpretation of Arabic algebra can be sustained in later texts.

Abū Kāmil uses the term restaurare (as the Latin translation for jabare) forty times in his Algebra. On other occasions he uses reintegrare or ikmāl as a synonym for restaurare. All occurrences have the same meaning as with al-Khwārizmī and can be reconciled with our new interpretation. For the third problem Abu Kāmil constructs the 'equation' $4 x=10-x$ and proceeds "Restaura ergo 10 per rem cum re, et appone adde rem 4 rebus; et erunt 5 res, equales 10 dragmis" (Sesiano 1993, 361:1117). ${ }^{24}$ Also here the restoration consists of completing the 10 and the following step is adding $x$ to the $4 x$. As with one case of al-Khwārizmī, the $j a b r$ operation with Abū Kāmil frequently refers to the restoration of a polynomial. For example the coequal polynomials

$$
42 \frac{1}{2} x-4 \frac{1}{4} x^{2}=100+2 x^{2}-20 x
$$

are restored as follows (Sesiano 1993, 365:1285-91):

Restaura ergo 100 dragmas et 2 census cum 20 radicibus, et adde illas ad 42 res et $1 / 2$ rei diminutis 4 censibus et $1 / 4$; et erunt 62 res et $1 / 2$ rei diminutis 4 censibus et $1 / 4$ census, equales 100 dragmis et 2 censibus. Restaura item 62 res et $1 / 2$ rei cum 4 censibus et $1 / 4$, et adde illos 100 dragmis et 2 et censibus; et erunt 100 dragme et 6 census et $1 / 4$ census, que equantur 62 rebus et $1 / 2$ rei.

The first restoration refers to the $100+2 x^{2}$, the second to $62 \frac{1}{2} x$.

Interestingly, the critical edition adds some omissions in the Latin translation which are present in an Arabic copy of the original. In this case the original had "Restaura ergo 100 dragmas et 2 census diminitus 20 rebus cum 20 radicibus". This reaffirms our interpretation of restoration as "restore <the defected polynomial $>$ with $<$ the part that was diminished $>$ ".

Jeffrey Oaks and Haitham Alkhateeb defend the position on the Historia Mathematica forum, that the al-jabr operation for $10 x-x^{2}=21$ should be interpreted as follows:

Think of $10 x-x^{2}$ as a diminished $10 x$. Its identity as $10 x$ is retained even though $x^{2}$ has been taken away from it. Its restoration to its former self is accomplished by adding $x^{2}$ to the other side of the equation.

This was answered by Luis Puig, who apparently raised the issue in a publication previously. ${ }^{25}$ In Puig's reconstruction of the al-jabr operation for the same problem, it is the $10 x$ which is restored: "Restaura luego las diez cosas del tesoro [substraído] y añádelo a veintiuno. Resulta entonces diez cosas, que igualan veintiún dirhams y un tesoro" (Puig 1998). On the discussion forum, Puig refers to the 
distinction made by al-Karkhī between nombres simples and nombres composés. This distinction is indeed quite relevant for an interpretation of the al-jabr operation. In the Al-Fakhrī, partially translated by Woepcke, al-Karkhī gives an introduction to algebra treating the multiplication of polynomials. A marginal comment on the distinction of the two types of 'numbers' is as follows (Woepcke 1853, 50):

Il y a des personnes qui sont d'avis que ce nombre $(10-a)$ est composé, puisqu'il est formé par deux expressions d'un ordre différent. Mais il n'est pas ainsi, parce que en disant: dix moins chose, vous indiquez un seul nombre de l'ordre des unités; si, au lieu de cela, il y avait eu : dix plus chose, cela aurait été composé. Cependant, placez les expressions de ce genre dans quelle catégorie vous voudrez, cela ne change rien aux principes du calcul.

The special status of 'incomplete' or 'defected' simple numbers can further explain the nature of the al-jabr operation. As the bone surgeon, algebrista in old Spanish, splints a broken leg, so does the al-jabr operation restore an incomplete number. ${ }^{26}$ While a negative term is considered a defect, the addition of a positive term is considered a constructive step for a composed number. It also explains that we should not consider the $-x^{2}$ in $10-x^{2}$ as a negative term, but as the defect of the incomplete number 10. While al-Karkhī's distinction between simple and composed numbers is essential in contextualizing the al-jabr operation, it cannot be stated that al-jabr refers to the completion of simple numbers only. In a problem of Abū Kāmil's Algebra, we find an interesting case in which the 'defected polynomial' consists of four terms (Sesiano 1993, 390-1):

Et si dicemus tibi: Divisi 10 in duas partes, et multiplicavi unam [in aliam] duarum partium in se et aliam in radicem 8 ; deinde proieci quod [agregatum] productum fuit ex multiplicatione unius duarum partium in radicem 8 ex eo quod provenit ex multiplicatione (alterius) in se, et remanserunt 40 dragme. Exemplum. Faciamus unam duarum partium rem, reliquam vero 10 diminuta re. Et ducamus 10 diminuta re in se, et erunt 100 dragme et census diminutis 20 rebus. Deinde multiplica rem in radicem de 8 , et proveniet radix 8 censuum. Quam prohice ex 100 dragmis et censu diminutis 20 rebus, et remanebunt 100 dragme et census 20 [radicibus] rebus diminutis et diminuta radice 8 censuum, que equantur 40 dragmis. Restaura ergo 100 et censum cum 20 [radicibus] rebus et radice 8 censuum, et adde (eas) ad 40 dragmas. Et habebis 100 dragmas et censum, que equantur 40 dragmis et 20 rebus et [rei] radici 8 censuum.

This solution of a division problem can be described symbolically as follows. Consider the two parts to be $x$ and $10-x$. Multiplying the second by itself and the first by the root of 8 , the difference equals 40 . Thus:

$$
(10-x)(10-x)-\sqrt{8} x=40
$$

Expanding the square of the second part and bringing the $x$ within the square root, this leads to

$$
100+x^{2}-20 x-\sqrt{8 x^{2}}=40
$$

So, now the question is, in al- Karkhī's terminology: what is restored here, the composed number $100+x^{2}$ or the simple number $x^{2}$ ? The text of Abū Kāmil 
leaves no doubt: "Restaura ergo 100 et censum cum 20 [radicibus] rebus et radice 8 censuum". Thus the polynomial

$$
100+x^{2} \text { is restored by } 20 x+\sqrt{8 x^{2}} \text {. }
$$

After that, the two terms are added to 40 . So, if close reading of the original text provides us with this divergent interpretation of the basic operation of Arabic algebra, why did scholars, proficient in Islam sciences and algebra fail to see it? Take for example Solomon Gandz, the leading expert on Arabic and Babylonian algebra in the early days of Isis and Osiris. Devoting an article on "The origin of the term "Algebra", Gandz (1926, 440) concludes that the al-jabr wa almuqābalah "ought to be rendered simply as Science of equations". Arguing against the older interpretation of restoration, he raises an intriguing question: "Why should we use an artificial surgical term for a mathematical operation, when there are such good plain words as $z \bar{a} d a$ and tamma for the operation of addition and completion?" (ibid., 439). This should indeed ring a bell. Maybe al-jabr is not just "a mathematical operation" as we tend to see it. Maybe the operation is something very different from addition. The specific choice of the term al-jabr instead of other "good plain words" deserves an explanation within the context of early Arabic algebra and is no argument against an interpretation as restoration.

\subsubsection{Older Interpretations}

Troubled by the question why the interpretation of al-jabr, as the restoration of a defected polynomial, is virtually absent in the twentieth century, we looked at some earlier studies. In Chasles (1841, 605-616) we recognize several important aspects of our interpretation:

Quand, dans un membre d'une équation, une quantité positive est suivie ou affectée d'une quantité négative, on restaure la quantité positive, c'est-à-dire qu'on la rétablit dans son intégralité. Pour cela on ajoute aux deux membres de l'équation une quantité égale, au signe près, à la quantité négative. Dans le langage de notre algèbre actuelle, nous dirions qu'on fait passer la quantité négative, du membre où elle se trouve, dans l'autre membre. Mais les Arabes ne pouvaient s'éxprimer ainsi, parce qu'ils ne considéraient pas de quantités négatives isolément. Quoi qu'il en soit, c'est, à mon sens, cette opération de restauration, telle que je viens de la définir, que les Arabes ont appelée jebr, et les traducteurs algebra.

He considers al-jabr as a restoration of a positive quantity to its original integrity. In doing so, one must "add an equal quantity to the two members of the equation". Chasles rightly adds that isolated negative quantities are not recognized in Arabic algebra.

Woepcke $(1854,365)$ is less concerned with the aspect of restoration and considers $a l-j a b r$ as "the action of removing a negative particle and consequently replacing it at the other member to conserve the equality". ${ }^{27}$ Rodet $(1878,38)$, based on the authority of Freytag (1830) for a translation of jabara as "post paupertalum ditivait", uses enrichissant. Thus he interprets the restoration of $100-20 x=40$ by al-Khwārizmī as: 
Il commence par faire disparaître le terme négatif - 20x, en enrichissant, comme il dit, les 100 unités de déficit que leur a causé la soustraction des $20 x$. Pour compenser cet enrichissant, il doit naturallement ajouter $20 x$ dans le second membre de l'equation.

Carra de Vaux (1897) wrote a short note on the meaning of al-jabr in Bibliotheca Mathematica after inspecting a manuscript of Ibn El-Hāim in the Ambrosiano Library in Milan (\&, 64, sup. f. $\left.28^{r}\right)$. In that text the term is also applied to the restoration of a quantity with a missing fraction: "Thus to make $5 / 6$ equal to one whole, you divide 1 by $5 / 6$ which leads to $1+1 / 5$ and then multiply it with $5 / 6$. Otherwise, you can take the difference of $1-5 / 6$ and $5 / 6$ which is $1 / 5$ and this you add to $5 / 6$ to obtain one". There is one occasion in al-Khwārizmı̄’s problems in which the same operation is performed. In problem III.13, discussed above complere was used in the same way. By using the same term for the operation, al-Khwārizmī shows that adding

$$
\frac{1}{3} x^{2} \text { to } x^{2}-\frac{1}{3} x^{2}
$$

is basically the same act as restoration $\frac{2}{3} x^{2}$ back to the form $x^{2} \cdot{ }^{28}$

Carra de Vaux's note also includes a reference to the encyclopedia of the Turkish historian Hādjī Khalīfa (c. 1650). Here a definition of djebr is given strong support for our favored interpretation: “le djebr c'est ajouter ce qui manque à l'une des deux quantités mises en équation pour qu'elle devienne égale à l'autre". 29

It is with some surprise that we have to admit the relevance of the nineteenthcentury analyses in the current discussions on the interpretation of Arabic algebra. It seems that with Hankel and Cantor the interpretation as adding the term to both parts of an equation, was generally accepted. ${ }^{30}$ Many twentieth-century authors have neglected to look up the studies of nineteenth-century scholars and missed their valuable comments. ${ }^{31}$

In summary, we believe that the al-jabr operation in early Arabic algebra can be characterized as follows:

- An operation aiming at the restoration of a defected quantity to its original completeness.

- The restored quantity could initially have been a simple number in the sense of al-Karkhī, but for Abū Kāmil it also applies to polynomials.

- The operation is probably derived from or to be interpreted in a geometrical sense.

- The operation is not performed on an equation but on the affected part of one of two coequal polynomials.

- The addition of the defected part to the coequal polynomial is not a part of but a consequence of the operation. 


\subsubsection{Al-muqābala}

The second operation, al-muqābala, is generally understood as the addition of homogeneous terms in a polynomial. So the operation allows to rewrite $100+x^{2}-20 x+x^{2}$ as $100+2 x^{2}-20 x$ (from al-Khwārizmī's third problem, Hughes 1989, 58). The Latin word for this is simply summa and derived from its geometrical interpretation of adding areas together. A second, equally important meaning of al-muqābala is the elimination of a term by subtracting it from the coequal polynomial. The Latin term for this is opponere and is used in problem III.5 of al-Khwārizmī’s Algebra (Hughes 1989, 56:3):

habebis 100 et duas substancias absque 20 radicibus 58 coequantes. Comple igitur 100 et 2 substancias cum re quam diximus et adde eam super 58 , et fient 100 et due subtancie, 58 et 20 res coequancia. Hoc igitur oppone id est ex numero 29 proicias et remanebunt 21 et substancia 10 res coequancia.

Thus al-Khwārizmī applies al-jabr to $100+2 x^{2}-20 x=58$ in order to restore $100+x^{2}$, translated on this occasion by complere. Omitted here by the scribe is a step which divides both polynomials by two to arrive at the coequal $50+x^{2}=29+10 x$. Then he applies al-muqäbala to eliminate the number 29 from the second polynomial by subtracting it from the first, resulting in $21+x^{2}=10 x$. Hughes $(1989,20)$ understands the division by two as complere, but we believe this to be mistaken, as complere is also used, in the meaning described here, in problem two of the second chapter "habebis 40 et 20 res 100 coequantes. Hec ergo centeno opponas numero et 40 ex 100 auferas et remanebunt 60, 20 res coequancia" (Hughes 1989, 57/23). Rosen (1831, 40), who used the Arabic manuscript, does include the missing step as "Reduce this to one square, by taking the moiety of all you have. It is then: fifty dirhems and a square, which are equal to twentynine dirhems and ten things". The Latin translation of Abū Kāmil's Algebra paraphrases muqābala as mukabala or mucabele and explains it as oppositio (Sesiano 1993, lines 527 and 532), but does not use the term within the problems. The verb complere only appears in its strict geometrical sense. Saliba $(1972,199)$ finds only one occasion in which al-Karkhī uses muqābala in the same sense as alKhwārizmī. He believes that al-Karkhī also uses muqābala for the two operations discussed below.

While our interpretation of al-jabr considers the operation of completion as distinct from the subsequent step of adding the completed part to the coequal polynomial, al-muqābala appears to operate on the coequal polynomials within the same operation.

\subsubsection{Al-radd and al-ikmāl}

The last two operations called al-radd and al-ikmāl are less controversial. They normally refer respectively the division or to the multiplication of coequal polynomials by a constant. However, in some cases $i k m a \bar{l}$ is used synonymously with jabr by Abū Kāmil and tamma (to complete) for the ikmāl operation. 
Table 3 Terms for the basic operations of Arabic algebra compiled from the main Latin translations

\begin{tabular}{|c|c|c|c|c|}
\hline Arab & الجبر al-jabr & $\begin{array}{l}\text { al-muqābala } \\
\text { المقابلة }\end{array}$ & $\begin{array}{l}\text { al-radd } \\
\text { الردد }\end{array}$ & $\begin{array}{l}\text { al-ikmāl } \\
\text { الإكمال }\end{array}$ \\
\hline $\begin{array}{l}\text { Rosen } \\
\text { (from Arab) }\end{array}$ & $\begin{array}{l}\text { reduce } \\
\text { separate }\end{array}$ & reduce & reduce & complete \\
\hline Robert of Chester & $\begin{array}{l}\text { restaurare } \\
\text { complere }\end{array}$ & opponere & converte & complere \\
\hline $\begin{array}{l}\text { Karpinski } \\
\text { (from Robert) }\end{array}$ & $\begin{array}{l}\text { restore } \\
\text { complete }\end{array}$ & by opposition & reduce & complete \\
\hline Gerard & restaurare & opponere & reducere & reintegrare \\
\hline Guglielmo & restaurare & eicere & reducere & $\begin{array}{l}\text { restaurare } \\
\text { reliquitur integer }\end{array}$ \\
\hline Abū Kāmil & $\begin{array}{l}\text { restaurare } \\
\text { reintegrare }\end{array}$ & opponere & reducere & $\begin{array}{l}\text { complere } \\
\text { (geometrical) }\end{array}$ \\
\hline
\end{tabular}

The best reference problem is problem III.5, as it combines the first three operations in a single problem solution. While Robert leaves out the al-radd step, he uses the verb converte for reducing the square term in problems III.3 and III.12 ("ergo ad unam converte substanciam"). The completion of the square term appears in problems III.4 and III.6.

\subsection{Operations on Equations in the Abacus Tradition}

In the course of the fourteenth century, the original context of al-jabr as restoring a defected or incomplete quantity was almost entirely abandoned. The initial $a l-j a b r$ operation, acting on a single quantity was extended by Abū Kāmil to be applied on polynomials. While the Arabic understanding of the operation continues to be present in some Latin treatises, we witness a clear shift in meaning of the operation.

With Fibonacci's Liber Abbaci and the early vernacular algebra texts, the operation acts simultaneously on two coequal polynomials. The relation between the words used for restoration and its etymological root becomes disconnected. In the beginning of the fourteenth century, restoration involves both the addition and the subtraction of a term to coequal polynomials, sometimes within the same derivation. With Maestro Biagio, from the fourteenth century onwards, the terminology discards all references to the restoring aspect and simply operates on both parts in order 'to level out' the positives as well as the negatives. The simultaneous operation on coequal polynomials is the beginning of what constitutes an algebraic equation. We cannot yet consider ragguagliare as an operation on an equation, but the simultaneous addition, subtraction, division and multiplication of coequal polynomials by some quantity contributes to the further transformation of this structure into a symbolic equation. 


\section{Conclusion}

The symbolic equation has resulted from a series of developments in algebraic practice spanning a period of three centuries. The concept of a symbolic equation as it emerges in algebra textbooks around 1550 is fundamentally different from the 'equation' as known before the sixteenth century. This transformation of the equation concept was completed through the practice of algebraic problem-solving. We can distinguish several phases of development which were necessary to realize the modern concept of an equation. We will now summarize these developments as discussed here, and place them within a broader framework. We will present them in logical order which does not perforce coincide with consecutive historical events. Several of these developments overlap and have reinforced each other.

\subsection{The Expansion of Arithmetical Operators to Polynomials}

A process of expansion and generalization has allowed applying the operations of addition, subtraction, division and multiplication to other entities than natural numbers. This expansion process can be looked at from the viewpoint of the objects as well as of the operators. Operations on polynomial terms emerged as an expansion of the operators. These were introduced in Hindu texts around 600 and in Arabic algebra before 800. Essential differences in approach suggest an independent development in these two traditions. The presentation of operations on polynomials together with or following the operations on irrational binomials provides strong support for a historic process of generalization from irrationals to algebraic polynomials. We have written evidence that operations on polynomials were introduced in Europe through the Latin translations of Arabic works on algebra. Possibly there has been some influence too from Hindu algebra through subscientific traditions. The abacus tradition paid little attention to a formal treatment of operations on polynomials. Only from the end of the fourteenth century some abacus treatises devote a section to the multiplication of binomials or trinomials. Early German cossist texts of the fifteenth century were the first to formally introduce these operations. They reflect the structure of an algorism applied to terms involving unknowns. By the beginning of the sixteenth century every serious work on algebra has an introduction explaining at least addition, subtraction and multiplication of algebraic polynomials.

\subsection{The Expansion of the Number Concept}

The process of applying arithmetical operations on terms with unknowns invoked an expansion of the number concept. The cossist tradition forwards the idea, which later becomes omnipresent in algebra textbooks, that cossic numbers are 
some kind of number, next to whole numbers, fractions and surds. Systematic treatments of arithmetic and algebra typically include binomials in the exposition of the numeration, the types of numbers in arithmetic. This evolution culminates in the Arithmetica of Cardano (1539). Cardano departs from the prevailing structure and treats the operators one by one. For each operation he discusses its application to whole numbers, fractions, irrationals and polynomial expressions. Polynomials, which he calls de numeratione denominationem, are thus presented as part of the number concept. The idea of polynomials as numbers is abandoned by the end of the sixteenth century. Later interpretations of higher-order polynomials with multiple roots and the unknown as a variable are in direct contradiction with a cossic number having one determinate arithmetical value.

\subsection{Equating Polynomial Expressions}

The very idea of an equation is based on the act of equating polynomial expressions. In fact, the Latin terms aequatio and aequationis refer to this action. Also the Sanskrit words samīkarana, samīkarā, or samīkriyā, used in Hindu algebra can be interpreted in this way. The word sama means 'equal' and kri stands for 'to do'. The meaning of an equation in the first Latin texts is most correctly conveyed by the terminology used by Guglielmo de Lunis and Robert of Chester. The term coaequare denotes the act of keeping related polynomials equal. The whole rhetoric of abacus texts is based on the reformulation of a problem using the unknown and the manipulation of coequal polynomials to arrive at a reducible expression in the unknown. One looks in vain for equations in abacus texts. Every reference to an equation is purely rhetorical, meaning that the only equation discussed is that $<$ coequal polynomial $1>$ equals $<$ coequal polynomial $2>$. If the manuscript contains illustrations or marginal comments then these are always polynomials or operations on polynomials. Only by the end of the fifteenth century do we find equations in the non-rhetorical meaning. They first appear in German texts such as the Dresden C 80. Apparently Italian algebra was too dependent on a rigid rhetorical structure to view an equation as a separate entity. Pacioli's Summa (1494), full of marginal illustrations, does not give a single equation. ${ }^{32}$ In Rudolff (1525) and Cardano (1539) we find the first illustrations of an equation in print. Both in the literal and the historical sense, we find the construction of an equation by equating polynomials (see Fig. 3, from Cardano 1539, 82).

\subsubsection{6 co.5.144 ce. $4356 . \mathrm{m}_{2} .2904$ co.i.⿲.1452 ce. 4160.xqualia 3240 c0.p.1596ce.}

Fig. 3 Cardano's construction of an equation by equating polynomial expressions 


\subsection{Operations on Coequal Polynomials}

The concept of an equation is shaped by the operations on coequal polynomials. The early development of the equation concept is determined by the first Arabic texts on algebra. Arabic algebra emerged from several competing traditions which are reflected in the meaning of the unknown and the operations allowed on coequal polynomials. These influences are most likely the 'high' tradition of calculators and the 'low' tradition of practical surveyors. A third influence of solving recreational problems concerning possessions may stem from Indian practice. The conceptual ambiguity of the $m \bar{a} l$, the unknown in Arabic algebra, can be explained through this diversity of influences. Also the al-jabr, the basic operation of Arabic algebra is challenging for a modern interpretation. Early Arabic texts interpret al-jabr as the restoration of a defected polynomial. The restoration of such polynomial to its integral (positive) form requires the subsequent step of adding the restored term to the coequal polynomial. This operation has transformed into the more general addition of terms to coequal polynomials. The characterization of the al-jabr as the restoration of one defected polynomial depends on the distinction made between co-equal polynomials and equations. When viewing Arabic algebra as operating on equations, such an interpretation would be meaningless.

Other operations such as bringing together homogeneous terms and dividing or multiplying coequal polynomials by a common factor can be related directly to their Arabic archetypes. These operations have been applied and discussed only implicitly in abacus problem-solving. An explicit or formal exposition of the possible operations on coequal polynomials is first seen by the end of the fifteenth century in Germany. The formulation of rules and making these operations explicit contributed to the idea of operating on a single algebraic entity. It will take two more centuries to formulate these rules as axioms of algebra.

\subsection{Expansion of Arithmetical Operators to Equations}

The transformation of operations on coequal polynomials to operations on equations is a subtle one. Only by making the distinction between the two can we understand and discern the changes in the concept of an equation.

The first explicit use of a multiplication of an equation is found in Cardano $\left(1539\right.$, f. $\left.H H 1^{r}\right)$ where he uses two unknowns to solve a linear problem. Eliminating one unknown, he arrives at an equation, expressed in the second unknown, which he multiplies with 35 , as shown in Fig. 4. Operating on equations here is closely connected with the use of the second unknown.

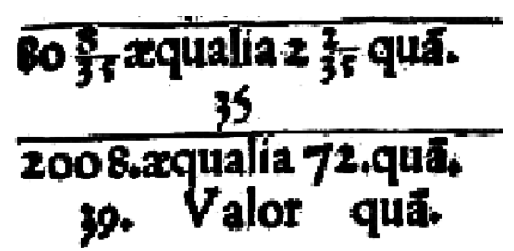

Fig. 4 First operation on an equation in Cardano's Arithmetica Practicae 


\subsection{Operations Between Equations}

The second unknown has been the driving force behind the introduction of operations between equations. Cardano (1545) not only performs operations on equations but also he was the first two subtract equations in order to eliminate one of the unknowns (Opera Omnia, III, 241) (see Figure 5).

Using Cardano's method of eliminating a second unknown from the Ars Magna and Stifel's extension of algebraic symbolism for multiple unknowns, Jacques Peletier (1554) operates on an aggregate of linear equations.

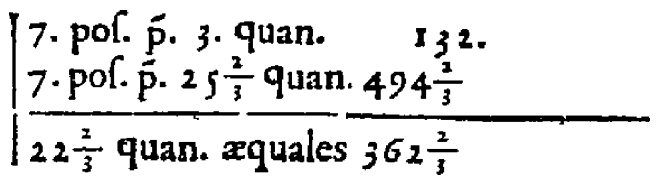

Fig. 5 Cardano (1545) subtracts the first equation from the second to result in the third

He adds and subtracts pairs of equations in a systematic way to solve a set of linear equations. Buteo's text (1559 corresponds closely with our meta-description in modern symbolism. The concept of a symbolic equation can thus be regarded as completed. The method was further refined by Gosselin (1577) from which we know that he had some influence on Viète (Cifoletti 1993).

\section{Epistemological Consequences}

We have presented a detailed analysis of the basic concepts of algebra since the first extant texts in the Arab world and their subsequent introduction in western Europe. The basic concepts of algebra are the unknown and the equation. We have demonstrated that the use of these concepts has been problematic in several aspects. Arabic algebra texts reveal anomalies which can be attributed to the diversity of influences from which the al-jabr practice emerged. We have characterized a symbolic equation as a later development which builds upon the basic Arabic operations on coequal polynomials. The concept of an equation can be considered as a solidification of the possible operations on coequal polynomials. In this way, the equation sign, as it was introduced by Robert Recorde (1557), represents not only the arithmetical equivalence of both parts, but at the same time symbolizes the possible operations on that equation. The equation, the basis of symbolic algebra, emerged from the basic operations on pre-symbolic structures, as we have studied them within Arabic algebra. The equation became epistemological acceptable by the confidence in the basic operations it represented. Knowledge depending on this new concept, such as later algebraic theorems or problems solved by algebra, derived their credibility from the operations accepted as valid for the concept. This new mathematics-as-calculation, derived from Arabic algebra, became the interpretation of mathematical knowledge in the sixteenth and seventeenth centuries. The introduction of symbolism allowed for a further abstraction from the arithmetical content of the algebraic terms. Operating on and between 
equations became such powerful tool that it standed as a model for a mathesis universalis, a normative discipline of arriving at certain knowledge. This is the function Descartes describes in Rule IV of his Regulae. Later, Wallis (1657) uses Mathesis Universalis as the title for his treatise on algebra. As a consequence, the study of algebra delivered natural philosophers of the seventeenth century a tool for correct reasoning in general. In the early modern period, algebra functioned as a model for analysis, much more than Euclidean geometry did.

Acknowledgments This chapter is a shortened and slightly revised version of chapter 6 of my $\mathrm{PhD}$ dissertation, From Precepts to Equations: The Conceptual Development of Symbolic Algebra in the Sixteenth Century, supervised by Diderik Batens, Ghent University Belgium. Funding for this research was provided by the research project G.0193.04 from the Flemish fund for scientific research (FWO Vlaanderen). I would like to thank Jan Hogendijk, Roland Hissette and Saskia Willaert for their comments on an earlier version of this text and Joris van Winckel for his help in the understanding and transcription of some central Arabic terms and their lexical intricacies.

\section{Notes}

1. Although it has been argued that Fibonacci used a Latin translation of al-Khwārizmī's Algebra, particularly Gerard of Cremona's translation (Miura 1981, 60; Allard 1996, 566), one has to account for the fact that he had direct access to Arabic sources. Leonardo was educated in Bugia, at the north of Africa, now Bejaje in Algeria, and travelled to several Arabic countries. He writes in his prologue of the Liber Abbaci that he "learnt from them, whoever was learned in it, from nearby Egypt, Syria, Greece, Sicily and Provence, and their various methods, to which locations of business I travelled considerably afterwards for much study" (Sigler 2002, 15-6).

2. Possibly two different authors are referred to by that name. For more details see Burnett (2002).

3. al-Khwārizmī's Algebra contains several problems which have been numbered in some translations. We will use the part numbers of the treatise as Roman numerals, followed by the sequence number and refer to the Latin translation if the problem numbering differs. Problem III.11 in Robert's translation is as follows: 'Terciam substancie in eius quartam sic multiplico, ut tota multiplicacionis summa ipsi coequetur substancie’ (Hughes 1989, 61). The problem is given by Karpinski in modern symbolism as

$$
\left(\frac{x}{3}\right) \cdot\left(\frac{x}{4}\right)=x \text {, while the form }\left(\frac{x^{2}}{3}\right) \cdot\left(\frac{x^{2}}{4}\right)=x^{2}
$$

would be more consistent with his interpretation of the $m \bar{a} l$.

4. Also argued by Høyrup (1998, note 11).

5. For a representation of $m \bar{a} l$ as a geometrical square see Fig. 2 in the discussion on $a l-j a b r$ below.

6. As pointed out by Allard $(1997,221)$ terminology is not always used consistently between translators and even by a single translator.

7. Hughes $(1989,18-9)$. Apparently Hughes mixes up the chapter numbering. Read instead "problems four and six of part II and in five, ten, and thirteen of part III".

8. This problem is numbered 14 in chapter VIII of the Gerard's translation (Hughes 1986, 260).

9. A preliminary version of both these articles came to our attention when this text was already written. The analysis of Oaks and Alkhateeb (2005) and especially their section on 'the deliberate shift from the original $m \bar{a} l$ to the algebraic $m \bar{a} l$ ' agrees with our observation. In fact, they discern three different meanings for $m \bar{a} l$. For the third meaning, they refer to the "division rule". If the result of the division of $a$ by $b$ is $c$, then the value of the $m \bar{a} l a$ can be "recovered" by multiplying $b$ and $c$. 
10. We will follow the analysis of Rodet $(1878,84-8)$. The English translation is from Colebrooke $(1817,208)$.

11. Heeffer, A.: "The Regula Quantitatis: From the Second unknown to the Symbolic Equation", forthcoming.

12. f. $155^{\mathrm{v}}$; Franci and Pancanti, 1988, 54: "Quando le chose sono iguali a censi ed al numero prima si parta ne' censi e poi si dimezi le chose e l'una metà si multripica per se medesimo e di quella multripicazione si tralgha il numero, la radice del rimanente agiunto overo tratto dall'altra metà delle chose, chotanto varà la chosa e tieni a mente che sono quistioni dove di bisogno agiugnere la metà delle chose e sono di quelle che àno bisogno di trarre del la metà delle chose e sono di quelle che per l'uno e per l'al tro si solvono. Esenpro al'agiugnere, prima dirò chosì".

13. Fibonacci, Liber Abbaci, second edition of 1228, on which Boncompagni's transcription is based. Høyrup (2002) suggests that the inconsistencies stem from the later additions and believes there must have existed an Italian vernacular text from before 1228 in which the term avere was used.

14. Although Hughes $(1986,1989)$ consistently talks about equations, he implicitly agrees with this position when he writes that Gerard "uses the word questio to signify our term equation" (Hughes 1986, 214).

15. From the English edition, Wallis 1685,2 . Chasles $(1841,612)$ criticises Wallis for the algebraic interpretation of the terms al-jabr and al-muchäbala as synthesis and analysis. However, Chasles has been very selective in his reading of the Treatise on Algebra.

16. The discussion has been archived at $\mathrm{http}: / /$ mathforum.org $/ \mathrm{kb} /$ forum.jspa? forumID $=149 \&$ start $=0$

17. From van der Waerden $(1985,4)$. Compare with "Addition gleicher Terme zu beiden Seiten einer Gleichung, um subtraktive Glieder zu elimineren", Alten et al. $(2003,162)$ and "to add the absolute value of a negative term from one side of an equation to itself and to the other side", Hughes 1986, 218. Hughes $(1989,20)$ defines the synonymous Latin term complere as "to transfer a term from one side of the equation to another".

18. Axioms play a role in the formulation of algebraic theory only from the seventeenth century.

19. Rosen 1831, 42, 43, 47, 48, 52, 52, for the problems discussed below. Problems of section VIII (in Gerard's translation) do not appear in the Arabic manuscript.

20. There exist two copies of an Arabic manuscript by Abd al-Hamīd ibn Wāsic ibn Turk, called Logical Necessities in Mixed Equations, studied by Sayili (1985). There are good reasons to believe that this work on algebra predates the one of al-Khwārizmī’s. Interestingly, except for the title, there is no reference to $a l-j a b r$.

21. This is the same formulation as the version of Libri (1938, I, 275), from the Paris Latin 7377A.

22. Some clarifications may be necessary. The solution to VII.1 possibly contains a scribal error. Before the restoration step, $(10-x)$ is multiplied with $x$. Consistent with the other cases, the restoration thus refers to $10 x$, instead of $10-x$ as in the text. Problem VI.5 refers to "the roots that have been diminished", thus $20 x$.

23. Problems 1, 3, 5, 7, 8, 9, 10 and 11 in the numbering by Kaunzner (1986).

24. The line numbers from the Sesiano transcription are given after the column. Some other examples from Sesiano (1993): "Restaura ergo eas cum 9 rebus" (1132), "Restaura 10 radices per censum" (1174), "Restaura igitur 100 dragmas cum 20 rebus" (1243).

25. Puig 1998, 16, discussed in the Historia Mathematica mailing list.

26. For the meaning of algebrista see Smith (1958, II, 389). For a quotation from Don Quixote see Cantor 1907, I, 679, note 3, and Kline 1964, 95).

27. Woepcke 1854, 365 : “Algèbre signifie dans la langue technique l'action, d'ôter la particule de la négation et ce qui la suit, et de reporter, en conservant l'égalité dans l'autre membre".

28. Hughes $(1989,18-9)$ misses the point when he writes in his commentary that al-Khwārizm "does not use the multiplicative inverse to obtain $x^{2}=71 / 2$ " and that this "must have jolted Robert's readers". However, the performed operation is perfectly comprehensible given our interpretation of al-jabr. 
29. Translation by Carra de Vaux, from Flügel 1835-58, II, 582.

30. Cantor (1907, I, 676) uses Wiederherstellung as the German translation of al-jabr and defines it as follows: "Wiederherstellung ist genannt, wenn eine Gleichung der Art geordnet wird, dass auf beiden Seiten des Gleichheitszeichens nur positive Glieder sich finden". This is a curious definition as the equation sign appeared only in Recorde (1557). Hankel even cites the Arithmetica of Diophantus as a source for the al-jabr of the Arabs: "Wenn aber auf der einen oder auf beiden Seiten negative Grössen vorkommen, so muss man diese auf beiden Seiten addiren, bis man auf beiden Seiten positive Grössen erhält' und das ist al gebr”. The quotation is taken from the Bachet (1621), Diophanti Alexandrini Arithmeticorum, p. 11 .

31. A notable exception is Tropfke (1933, II, 66): "In dem Beispiele $13 x-5=7 x+4$ ist die linke Seite unvolständig, da ein fehlendes Glied vorkommt; si mu $\beta$ also mit 5 ergänzt werden, die dann auch rechts hinzuzufügen ist". This interpretation is not respected by the editors of the 1980 edition.

32. Except for the standard rules of algebra, the six Arabic types and two impossible cases (Pacioli 1494, f. 149 ${ }^{\mathrm{r}}$.

\section{References}

\section{Manuscripts Cited}

Florence, Biblioteca Riccardiana, 2263 (transcription by Simi, 1994)

Florence, BNCF, Fond. princ. II.V.152 (fols. $145^{\mathrm{r}}-180^{\mathrm{v}}$, transcription by Franci and Pancanti, 1988)

Istanbul, Kara Mustafa Kütübhane 379 (partial transcription by Levey, 1966)

Madrid, Codex Escurialensis, fondo Arabe 936 (transcription and Spanish translation by Sánchez Pérez, 1916)

Milan, Ambrosiano P 81 sup (transcription and Italian translation by Picutti, 1983)

Modena, Biblioteca Estense, Ms. Ital. 587 (partial transcription by van Egmond, 1986)

Munich, Bayerischen Staatsbibliothek, Codex Latinus Monacensis 26639 (transcription by Kaunzner, 1978)

Oxford, Bodleian Library, CMXVIII Hunt. 214 (transcription and English translation by Rosen, 1831)

Paris, BNF, Lat. 7377A (fols. 34 $-43^{\mathrm{v}}$, transcription by Libri, 1838, I, pp. 253-297).

Paris, BNF, Lat. 7377A (fols. 58 ${ }^{\mathrm{v}}-68^{\mathrm{r}}$, transcription by Libri, 1838, I, pp. 304-372).

Paris, BNF, Lat. 7377A (fols. $71^{\mathrm{v}}-93^{\mathrm{v}}$, transcription by Sesiano, 1993)

Paris, BNF, anciens fonds nr. 7266 (unpublished)

Siena, Bibliotheca Comunale, Codice I.VII.17 (transcription by Franci, 2001)

Siena, Bibliotheca Comunale, Codice L.IV.45 (transcription by Santini, 1982)

Turin, Bibliotheca Nazionale, Codice N. III; 53 (transcription by Rivoli, 1983)

Vatican, Barberini Orientale 36,1 (transcription by Anbouba, 1964)

Vatican, Lat. 4826 (fols. 36v-45v, transcription and translation by Høyrup, 2000)

Vienna, Österreichischen Nationalbibliothek, Codex Vindobonensis 5277 (transcription by Kaunzner 1972)

\section{Primary Sources}

Buteo, Johannes: 1559, Logistica, quae et arithmetica vulgo dicitur, in libros quinque digesta... Ejusdem ad locum Vitruvii corruptum restitutio..., Lyon.

Cardano, Girolamo: 1539, Practica arithmetice, \& mensurandi singularis. In qua que preter alias cōtinentur, versa pagina demonstrabit, Bernardini Calusci, Milan. 
Cardano, Girolamo: 1545, Ars Magna sive de regulis algebraicis, Johann Petreius, Nürnberg.

Gosselin, Guillaume: 1577, De arte magnam. De Occula Parte Mathematicarum, qua et Algebra et Almacabala vulgo dicitur, libri IV, Aegidium Beys, Paris.

Pacioli, Lucca: 1494, Summa de arithmetica geometria proportioni : et proportionalita. Continetia de tutta lopera, Paganino de Paganini, Venice.

Peletier, Jacques: 1554, L'algebre de Iaques Peletier dv Mans, departie an deus liures, Jean de Tournes, Lyon.

Recorde, Robert: 1557, The whetstone of witte whiche is the seconde parte of Arithmetike: containyng thextraction of rootes: the cossike practise, with the rule of equation: and the woorkes of surde nombers. Though many stones doe beare greate price, the whetstone is for exersice ... and to your self be not vnkinde, By Ihon Kyngston, London.

Rudolff, Christoff: 1525, Behend vnnd Hubsch Rechnung durch die kunstreichen regeln Algebre so gemeincklich die Coss genent werden, Vuolfius Cephaleus Joanni Jung, Strassburg.

\section{Secondary Sources}

Allard, André: 1996, "The Influence of Arabic Mathematics in the Medieval West" in Rashed (ed.), 1996, Vol II, pp. 539-580.

Allard, André: 1997, "L' influence des mathématiques arabes dans l'occident médiéval, in Rashed (1997), vol. II, pp. 199-229.

Alten, Heinz-Wilhelm, Naini, Alireza Djafari, Folkerts, Menso, Schlosser, Hartmut, Schlote, Karl-Heinz, Wussing, Hans: 2003, 4000 Jahre Algebra. Geschichte, Kulturen, Menschen. Springer, Heidelberg.

Boncompagni, Baldassare: 1850-1, "Della vita e delle opere di Gherardo Cremonese traduttore del secolo XII. E di Gherardo da Sabbioneta astronomo del secolo 13", Tip. delle Belle Arti, Rome.

Boncompagni, Baldassare: 1857, Trattati d'arithmetica, Part II: Ioannis Hispalensis Liber algorismi de practica arismetrice, Typografia delle scienze Fissiche e Matematiche, Rome.

Boncompagni, Baldassarre: 1857, 1862, Scritti di Leonardo Pisano, matematico del secolo decimoterzo (2 vols.), Vol I.: Liber Abbaci di Leonardo Pisano. Vol II.: Leonardi Pisani Practica geometriae ed opuscoli. Tipografia delle Scienze Matematiche e Fisiche, Rome.

Burnett, Charles: 2002, "John of Seville and John of Spain: A mise au point". Bulletin de philosophie médiévale, 44, 59-78.

Busard, Hubertus Lambertus Ludovicus: 1968, "L'algèbre au Moyen Âge: Le «Liber mensurationum » d'Abû Bekr", Journal des Savants, Avril-Juin, 65-125.

Cantor, Moritz: 1880-1908, Vorlesungen über Geschichte der Mathematik, Bd. I., 'Von den ältesten Zeiten bis zum Jahre 1200 n. Chr.', third ed. (1907), Teubner, Leipzig.

Carra de Vaux Saint-Cyr, Bruno: 1897, 'Sur le sens exact du mot „al-jabr““, Bibliotheca Mathematica, F. 2, 11, 1-2.

Chasles, Michel: 1841, "Histoire de l'Algèbre", Comptes rendus hebdomadaires des séances de l'Académie des sciences, 13, part I, "Sur l'époque où l'Algèbre a été introduite en Europe", 497-542, part II, "Sur les expressions res et census. Et sur le nom de la science, Algebra et Almuchabala", 13, 567ff, $601 \mathrm{ff}$.

Cifoletti, Giovanna: 1993, Mathematics and rhetoric: Peletier and Gosselin and the making of the French algebraic tradition. $\mathrm{PhD}$, Princeton University 0181, Dissertation Abstracts International, 53, 4061-A.

Colebrooke, Henry Thomas: 1817, Algebra with Arithmetic and Mensuration from the Sanscrit of Brahmegupta and Bháscara. John Murray, London (reprint by Sandig Reprint Verlag Vaduz, Lichtenstein, 2001). 
Cossali, Pietro: 1797-9, Origine, trasporto in Italia, primi progressi in essa dell'algebra. Storia critica di nuove disquisizioni analitiche e metafisiche arricchita (2 vols.), Parmense.

Flügel, Gustav (ed.): 1835-1858, Lexicon bibliographicum et encyclopaedicum a Mustafa ben Abdallah Katib Jelebi dicto et nomine Haji Khalfa celebrato compositum. Ad codicum vindobonensium, parisiensium et berolinensium fidem primum edidit, latine vertit et commentario indicibusque instruxit Gustavus Fluegel, Leipzig.

Franci, Rafaella (ed.): 2001, Maestro Dardi (sec. XIV) Aliabraa argibra. Dal manoscritto I. VII. 17 della Biblioteca Comunale di Siena, Quaderni del Centro Studi della Matematica Medioevale, 26, Università degli Studi di Siena, Siena.

Franci, Raffaella: 2003, "Una traduzione in volgare dell'al-jabr di al-Khwarizmi (MS. Urb. Lat. 291 Biblioteca Apostolica Vaticana)" in R. Franci, P. Pagli, A. Simi (eds.), Il Sogno di Galois: Scritti di storia della matematica dedicati a Laura Toti Rigatelli per il suo $60^{\circ}$ compleanno. Centro Studio della Matematica Medioevale, Università di Siena, Siena, pp. 19-49.

Franci, Rafaella and Marisa Pancanti (eds.): 1988, Anonimo (sec. XIV). Il Trattato d'algibra dal manoscritto Fond. Princ. II.V.152 della Bibliotheca Nazionale di Firenze, Quaderni del Centro Studi della Matematica Medioevale, 18, Università di Siena, Siena.

Freytag, Georg Wilhelm: 1830, Georgii Wilhelmi Freytagii lexicon arabico-latinum praesertim ex Djeuharii Firuzabadiique et aliorum arabum operibus adhibitis golii quoque et aliorum libris confectum (4 vols.) Schwetschke, Halis Saxonum.

Gandz, Solomon: 1926, "The Origin of the term "Algebra", American Mathematical Monthly, 33, (9), 437-440.

Gandz, Solomon: 1932, "The Mishnat ha Middot, the First Hebrew Geometry of about 150 C.E., and the Geometry of Muhammad ibn Musa al-Khowarizmi, the First Arabic Geometry $<\mathrm{c}$. $820>$, Representing the Arabic Version of the Mishnat ha Middot. A New Edition of the Hebrew and Arabic Texts with Introduction, Translation and Notes", Quellen und Studien zur Geschichte der Mathematik, Astronomie und Physik, Abteilung A: Quellen 2.

Gandz, Solomon: 1937, "The Origin and Development of the Quadratic Equations in Babylonian, Greek, and Early Arabic Algebra", Osiris, 3, 405-557.

Hardy, Godfrey Harold: 1929, "Mathematical proof”, Mind, 38(4), 1-25.

Hispalensis, Johannes (see Boncompagni, 1857)

Hissette, Roland: 1999, "Guillaume de Luna a-t-il traduit Abû Kâmil?", in: G. Endress \& J.A. Aertsen (eds.), Averroes and the Aristotelian Tradition, Brill, Leiden, 300-315.

Hissette, Roland: 2003, "L'al-Jabr d'al-Khwârizmî dans les MSS. Vat. Lat. 4606 et Vat. Urb. Lat. 291 et Guglielmo De Lunis", Miscellanea Bibliothecae Apostolicae Vaticanae X. 137-158.

Hochheim, Adolph: 1878, Kafi fil Hisâb (Genügendes über Arithmetik) des Abu Bekr Muhammed ben Alhusein Alkarkhi., (3 vols.) Louis Nebert, Halle.

Høyrup, Jens: 1986, "Al-Khwārizmī, Ibn Turk, and the Liber Mensurationum: on the Origins of Islamic Algebra”, Erdem 2 (Ankara), 445-484.

Høyrup, Jens: 1990, "Algebra and Naive Geometry. An Investigation of Some Basic Aspects of Old Babylonian Mathematical Thought", Altorientalische Forschungen, 17, 27-69, $277-369$.

Høyrup, Jens: 1990a, "Sub-Scientific Mathematics. Observations on a Pre-Modern Phenomenon", History of Science, 28, 63-86.

Høyrup, Jens: 1994, In Measure, Number, and Weight, Studies in the Mathematics and Culture, State University of New York Press, Albany.

Høyrup, Jens: 1996, "The formation of a myth: Greek mathematics-our mathematics" in J. Gray, C. Goldstein, and J. Ritter (eds.), L'Europe mathematique / Mathematical Europe, Editions de la Maison des Sciences de l'homme, Paris, pp. 103-122.

Høyrup, Jens: 1998, "A new art in ancient clothes. Itineraries chosen between scholasticism and baroque in order to make algebra appear legitimate, and their impact on the substance of the discipline", Physis, 35 (1), 11-50.

Høyrup, Jens: 2000, "Jacobus de Florentia, Tractatus algorismi (1307), the chapter on algebra (Vat. Lat. 4826, fols 36v-45v)", Centaurus, 42 (1), 21-69.

Høyrup, Jens: 2002, Lengths, Widths, Surfaces: a Portrait of Old Babylonian Algebra and its Kin, Springer, Heidelberg. 
Høyrup, Jens: 2006, "Jacopa da Firenze and the beginning of Italian vernacular algebra", Historia Mathematica, 33 (1), 4-42.

Hughes, Barnabas: 1982, "The Medieval Latin Translations of Al-Khwārizmī's al-jabr", Manuscripta, 26, 31-37.

Hughes, Barnabas: 1986, “Gerard of Cremona's Translation of al-Khwārizmī’s al-Jabr: A Critical Edition", Mediaeval Studies, 48, 211-263.

Hughes, Barnabas B.: 1989, Robert of Chester's Latin Translation of of al-Khwārizmī's al-Jabr, Steiner, Stuttgart.

Karpinski, Louis Charles: 1914, “The Algebra of Abu Kamil”, American Mathematical Monthly, 21(2), 37-48.

Karpinski, Louis Charles: 1915, Robert of Chester's Latin Translation of the Algebra of AlKhwarizmi, Macmillan Company, New York (Reprinted by University of Michigan Press, Ann Arbor, 1933).

Kaunzner, Wolfgang: 1986, "Die lateinische Algebra in MS Lyell 52 der Bodleian Library, Oxford, früher MS Admont 612"' in G. Hamann (ed.), Aufsätze zur Geschichte der Naturwissenschaften und Geographie, Österreichische Akademie der Wissenschaften, Phil.Hist. Klasse, Sitzungsberichte, Bd. 475, Vienna, pp. 47-89.

Kitcher, Philip: 1984, The Nature of Mathematical Knowledge, Oxford University Press, Oxford.

Kline, Morris: 1964, Mathematics in western Culture, Oxford University Press, Oxford.

Lakatos, Imre: 1976, Proofs and Refutations, Cambridge University Press, Cambridge.

Levey, Martin: 1966, The algebra of Abu Kamil: Kitab, fi al-jabr wa al- muqabala in a commentary by Mordecai Finzi, The University of Wisconsin Press, Madison.

Libri, Guillaume: 1838, Histoire des sciences mathématiques en Italie, depuis la renaissance des lettres jusqu'à la fin du dix-septième siècle, Jules Renouard et Cie, Paris.

Mancosu, Paolo: 1996, Philosophy of Mathematics and Mathematical Practice in theSeventeenth Century, Oxford University Press, Oxford.

Miura, Nobuo: 1981, "The algebra in the 'Liber abaci' of Leonardo Pisano", Historia Scientiarum, International Journal of the History of Science Society of Japan, 21, 57-65.

Montucla, Jean-Etienne: 1799-1802, Histoire des mathématiques dans laquelle on rend compte de leurs progrès depuis leur origine jusqu'à nos jours, 4 vols., Agasse, Paris.

Nesselmann, Georg Heinrich Ferdinand (1842) Versuch einer kritischen Geschichte der Algebra. Vol 1. Die Algebra der Griechen, Berlin, (Reprint by Minerva, Frankfurt, 1969).

Oaks, Jeffrey and Haitham Alkhateeb: 2005, "Mal, enunciations, and the prehistory of Arabic algebra", Historia Mathematica, 32 (4), 400-425.

Pieraccini Licia (ed.): 1983, $M^{\circ}$ Biagio, Chasi exenplari alla regola dell'algibra. Nella trascelta a cura di Maestro Benedetto. Dal Codice L. VI. 21 della Biblioteca Comunale di Siena. A cura e con introduzione di Licia Pieraccini, Quaderni del Centro Studi della Matematica Medioevale, 5, Servizio Editoriale dell'Università di Siena, Siena.

Puig, Luis: 1998, "Componentes de una historia del algebra. El texto de al-Khwarizmi restaurado" in Hitt (ed.), Investigaciones en Matematica Educativa II. Mexico, DF: Grupo Editorial Iberoamerica, pp.109-131 (revised version 2003).

Rodet, Léon: 1878, "L'Algèbre d'al-Khārizmi et les méthodes Indienne et Grecque", Journal Asiatique, Série 7, 11, 5-98

Rosen, Frederic: 1831, The Algebra of Mohammed Ben Musa, The Oriental Translation Fund, London (Reprinted by Olms Verlag, 1986).

Ruska, Julius: 1917, "Zur ältesten arabischen Algebra", Sitzungsberichte der Heidelberger Akademie der Wissenschaften, Philosophisch-historische Klasse, 8, 14-23.

Saliba, George A.: 1972, "The meaning of al-jabr wa al-muqābalah", Centaurus, 17, 189-204.

Sánchez Pérez, José A. (ed., trans.): 1916, Compendio de algebra de Abenbéder. Texto arabo, traduccion y estudio, Junta para Ampliación de Estudios e Investigaciones Científicas, 47, Centro de Estudios Históricos, Madrid. 
Sayili, Aydin: 1985, Abdülhamîd İbn Türk'ün katişik deklemlerde mantikîzaruretler adli yazisi ve zamanin cebrî, Türk Tarîh Kurumu Basimevî, Ankara.

Sesiano, Jacques: 1993, "La version latine médiévale de l'Algèbre d'Abū Kāmil" in Menso Folkerts and J. P. Hogendijk (eds.), 1993, Vestigia Mathematica: Studies in medieval and early modern mathematics in honour of H. L. L. Busard, Rodopi, Amsterdam, pp. 313-452.

Sigler, Laurence: 2002, Fibonacci's Liber Abaci. A Translation into Modern English of Leonardo Pisano's Book of Calculation, Springer, Heidelberg.

Simi, Annalisa (ed.): 1994, Anonimo (sec. XIV). Trattato dell'Alcibra Amuchabile (Dal Codice Ricc. 2263 della Biblioteca Riccardiana di Firenze), Quaderni del Centro Studi della Matematica Medioevale, 22, Università di Siena, Siena.

Smith, David Eugene: 1923, 1925, History of Mathematics, 2 vols., Ginn and company, Boston (Dover edition 1958, 2 vols.)

Tropfke, Johannes: 1933-4, "Zur Geschichte der quadratischen Gleichungen über dreieinhalb Jahrtausend", (3 parts) Jahresbericht der Deutschen Mathematiker Vereinigung, 43, 98-107; 44, 26-47; 44, 95-119.

Toti Rigatelli, Laura: 1984, Dionigi Gori. Libro e trattato della Practicha d'Algibra dal Codice L.IV.22 della Biblioteca Comunale di Firenze, Quaderni del Centro Studi della Matematica Medioevale, 9, Università di Siena, Siena.

van der Waerden, Bachtel Leenert: 1985, A History of Algebra from al-Khwārizmī to Emmy Noether, Springer, Heidelberg.

van Egmond, Warren: 1983, "The Algebra of Master Dardi of Pisa", Historia Mathematica, 10, 399-421.

van Egmond, Warren: 1986, Della radice de' numeri e metodo di trovarla (Trattatello di Algebra e Geometria) dal Codice Ital. 578 della Biblioteca Estense di Modena. Parte Prima, Quaderni del Centro Studi della Matematica Medioevale, 15, Università degli Studi di Siena, Siena.

Wallis, John: 1685, A Treatise of Algebra Both Theoretical and Practical,: Printed by John Playford for Richard Davis, London.

Wappler, Hermann Emil: 1899, "Zur Geschichte der deutschen Algebra", Abhandlungen zur Geschichte der Mathematik, 9, 537-54.

Wittgenstein, Ludwig: 1974, Philosophical Grammar, Basil Blackwell, Oxford (1978, University of California press, Berkeley).

Weinberg, Josef: 1935, Die Algebra des Abu Kamil Soga' ben Aslam, Salesianische Offizin. Diss. Univ. München.

Woepcke, Franz: 1853, Extrait du Fakhrī: Traité d'algèbre par Aboū Bekr Mohammed Ben Alhaçen Alkarkhī (manuscrit 952, supplément Arabe de la Bibliothèque Impérial) Précédé d'un mémoire sur l'algèbre indéterminée ches les Arabes, L'imprimerie Impériale, Paris.

Woepcke, Franz: 1854, "Recherches sur l'histoire des sciences mathématiques chez les Orientaux d'après des traités inédits Arabes et Persans", Article I: "Note sur des notations algébriques employées par les Arabes", Comptes Rendus des Séances de l'Académie des Sciences, 39, 348-384. 